\title{
LAS APELACIONES ANTE LAS ASAMBLEAS PARLAMENTARIAS ESPAÑOLAS AL RESPETO A LA CONSTITUCIÓN HISTÓRICA PROPIA POR PARTE DE LA DIPUTACIÓN DE NAVARRA EN BAYONA Y CÁDIZ.
}

\section{APPEALS TO THE SPANISH PARLIAMENTARY ASSEMBLIES RESPECT TO OWN HISTORY CONSTITUTION BY THE DIPUTACIÓN OF NAVARRE IN BAYONNE AND CADIZ.}

\author{
Fernando Mikelarena Peña \\ Universidad de Zaragoza.
}

\begin{abstract}
SUMARIO: I. INTRODUCCIÓN.- II. ANTE LA ASAMBLEA DE BAYONA.- III. ANTE LAS CORTES DE CÁDIZ.- 1. La representación navarra en las Cortes de Cádiz.2. El intento de legitimar el nuevo orden constitucional gaditano con arreglo a los parámetros constitucionales propios.- 2.1. La abolición de la constitución histórica navarra por parte de la constitución española de 1812.- 2.2. La propuesta de agosto de 1813 de convocatoria de Cortes navarras para aprobar y jurar la constitución de 1812.- 2.3. Una posible razón añadida de la solicitud de 20 de agosto de 1813 de convocatoria de Cortes navarras. IV. A MODO DE CONCLUSIÓN.
\end{abstract}

Resumen: En este artículo se analizan las apelaciones ante las asambleas parlamentarias españolas al respeto a la constitución histórica propia por parte de la diputación de Navarra en Bayona y Cádiz. Dos aspectos son examinados: la representación en cuerpo extraño y la necesidad de convocatoria de las Cortes de Navarra para legitimar los cambios.

Absatract: This article discusses appeals before the Spanish parliamentary assemblies to respect their own historical constitution by the council of Navarre in Bayonne and Cadiz. Two aspects are examined: the representation in foreign body and the need to call for the Parliament of Navarre to legitimize the changes.

Palabras Clave: Constitución histórica, Navarra, Liberalismo, Absolutismo, Constitución Española, Asmablea de Bayona, 1808, Cortes de Cádiz, 1812..

Key Words: Historical constitution, Navarre, Liberalism, Absolutism, Spanish Constitution, Assembly of Bayonne, Cortes de Cádiz, 1812.

\section{INTRODUCCIÓN.}

En este artículo repasaremos las actitudes que mostró la Diputación de Navarra en relación con la necesidad teórica, según los cánones constitucionales propios navarros, de que las asambleas parlamentarias constituyentes españolas del periodo 1808-1814 (Asamblea de Bayona y Cortes de Cádiz) respetaran dos principios fundamentales de la Constitución Histórica de Navarra: el de la imposibilidad de representar en cuerpo extraño y el de la obligación por parte del 
rey de convocar a las Cortes navarras para que estas aprobaran cualquier modificación de aquélla. Como veremos, aquellas exigencias teóricas se vieron arrumbadas por la fuerza de las circunstancias en ambas ocasiones, si bien se pueden advertir algunos matices de interés en las apelaciones de la corporación navarra, así como en las respuestas que recibieron.

Antes de seguir, es preciso advertir que la Diputación navarra ya contaba con un precedente admonitorio. En 1789 los Estados Generales de la Baja Navarra trataron infructuosamente de argumentar que constituian un cuerpo político diferente de la monarquía francesa, no estando obligados a enviar representantes a los Estados Generales franceses, y que, de cualquier forma, la alteración del ordenamiento constitucional propio precisaba de la aquiescencia del órgano legislativo autóctono. A pesar de presentarse en la Asamblea Nacional Francesa en calidad de invitados, los delegados bajonavarros pudieron comprobar con crudeza que los diputados franceses hicieron oídos sordos a sus reivindicaciones, finalizando la cuestión con la adhesión de la Baja Navarra al reino de Francia al final del mismo año ${ }^{1}$

\section{ANTE LA ASAMBLEA DE BAYONA.}

Bayona en 1808 será la primera ocasión en la que la Diputación navarra se vió en el trance de participar en un foro parlamentario que reunía a los representantes de los territorios de la monarquía española.

El carácter extraordinario de la convocatoria en la Gazeta de Madrid del 24 de mayo de 1808 de una Diputación general de españoles para aprobar el proyecto de constitución elaborado por Napoleón para España, ahora gobernada por su hermano José I, tras las abdicaciones de Bayona, en la que se explicitaba que la Diputación navarra debía de enviar dos representantes, no se trasluce en las actas de la corporación foral. Y eso que la convocatoria era algo totalmente novedoso, ya que Navarra, al igual que los tres territorios vascongados, nunca había acudido a las Cortes de Castilla y León de la Edad Moderna, ni a las Cortes unificadas del siglo XVIII, por contar Navarra con sus propias Cortes y disponer las Provincias Vascongadas de sus Juntas Generales privativas. A esa novedad se añadía otra: en rigor, de acuerdo con los parámetros de funcionamiento de la constitución navarra, los representantes navarros debian ser designados por las Cortes navarras, nunca por la Diputación.

Seguramente a causa de las circunstancia de estar ocupada Navarra por los franceses desde mediados de febrero de 1808, las actas de la Diputación no revelan reacción alguna, siendo totalmente parcas y escuetas ${ }^{2}$. De hecho, los extremos que podemos apuntar a partir de dichas actas son de muy escaso interés. Podemos decir que en la sesión de 23 de mayo de 1808 se convocó una reunión para hablar de dicha convocatoria y que en las reuniones de la diputación de los dias 28 y 29 de mayo se habló del asunto y que, "aunque se

\footnotetext{
1 Fernando Mikelarena Peña, "La Constitución histórica Navarra y el surgimiento del estado liberal. El espejo bajonavarro en 1789", Historia constitucional: Revista Electrónica de Historia Constitucional, 14, 2013.

2 Archivo Real y General de Navarra (ARGN), Sección de Reino, Actas de la Diputación, Actas de la Diputación del 30 de septiembre de 1805 al 27 de agosto de 1808, folios 121 a 128.
} 
Las apelaciones ante las Asambleas parlamentarias españolas al respeto a la ...

conferenció largamente" en esas sesiones, no se tomó ninguna resolución. Si bien en ellas no se dice que se hablara del tema, aún cuando es de suponer que sí, en las sesiones de 30 de mayo y de 1 y 2 de junio tampoco se tomó ninguna resolución.

No obstante, a pesar de que no hayamos encontrado ningún reflejo de ello en las mencionadas actas, sabemos que el 28 de mayo la Diputación redactó una carta, de la que existe una copia en francés en el Archivo del Ministerio de Asuntos Exteriores galo, en la que advertía que carecia de la capacidad para designar representantes para una asamblea constituyente, con lo que, en el caso de que la Asamblea reunida en Bayona procediera a introducir cambios en la Constitución navarra, los poderes de los representantes navarros serían nulos, afectando eventualmente a la legalidad de la reunión ${ }^{3}$. En el mismo sentido, en un informe remitido el 4 de junio por un auxiliar de Laforest, embajador de Francia en Madrid, al Duque de Berg, lugarteniente general de España, se decía que las diputaciones de Navarra y Guipúzcoa "no se creen revestidas de los poderes necesarios para enviar a la asamblea de Bayona los miembros, que ellos estaban encargados de escoger"4.

A pesar de no haber recibido contestación a esa representación enviada el 28 de mayo en la que apuntaba que carecía de facultades para enviar diputados a la Junta de Bayona, la Diputación envió el 10 de junio una exposición, que se conserva entre los legajos relativos a la Guerra de Independencia del Archivo General de Navarra, también dirigida a Berg, comunicándole que, había nombrado, por "un efecto de su sumisión", a Miguel Escudero y a Luis Gainza como representantes del Reino de Navarra ${ }^{5}$. Berg manifestó su satisfacción. En el

3 Jean Baptiste Busaall, "Constitución histórica y revolución liberal: el reino de Navarra, ¿un modelo posible para la reforma institucional en las Cortes de Cádiz?”, en Jean Baptiste Busaall y Lartaun de Egibar Urrutia, Las instituciones del Reino de Navarra en el debate histórico jurídico de la revolución liberal, Pamplona, Universidad Pública de Navarra, 2005, p. 69.

4 Carlos Sanz Cid, La Constitución de Bayona. Labor de redacción y elementos que a ella fueron aportados, según los documentos que se guardan en los Archives Nationales de Paris y los Papeles Reservados de la Biblioteca del Real Palacio de Madrid, Madrid, Editorial Reus, 1922, p. 89.

5 De ambos, el único politicamente relevante era el primero. Escudero era miembro de la Diputación, elegido por el brazo militar en las Cortes de 1801. Como veremos, abandonará Pamplona, junto con la mayor parte del resto de la Diputación y junto con los sindicos, desmarcándose de la legalidad josefina, a finales de agosto de 1808. Más adelante, en 1813, fue nombrado Gefe Político de Navarra y también presidió la primera diputación provincial amoldada a la Constitución de 1812, pero, sin embargo, de signo profundamente absolutista a causa del carácter de sus integrantes. Tras 1814 volvió a ser diputado del Reino en la Diputación tradicional restaurada por Fernando VII. En el inicio del Trienio, a finales de marzo de 1820, según indican Mina Apat y Del Río Aldaz (Maria Cruz Mina Apat, Fueros y revolución liberal en Navarra, Madrid, Alianza, 1981, p. 62, nota 7 y pp. 85-86; Ramón Del Río Aldaz, Orígenes de la guerra carlista en Navarra, 1820-1824, Pamplona, Gobierno de Navarra, 1987, pp. 42-43), Espoz y Mina impidió que tomara posesión como jefe politico por sus afinidades con el realismo, siendo relevado finalmente por el gobierno de Madrid. Gaínza era militar y permanecería en el bando afrancesado, recibiendo en 1809 el grado de Caballero de la Real Orden de España de manos de José Bonaparte (Gazeta de Madrid de 27 de octubre de 1809) y ostentando algunos cargos en la monarquía josefina como el de comisario regio para Toledo y su provincia (Fernando Jiménez de Gregorio, Toledo y su provincia en la guerra de 1808, Toledo, Instituto Provincial de Investigaciones y Estudios Toledanos, 1980, p. 21). Un informe confidencial confeccionado a mediados de 1808 por un informador anónimo a sueldo de los franceses calificaba a Escudero como "un hombre inteligente muy vinculado a Francia, que detesta los Borbones y a Godoy" y señalaba a Gainza como "un fiel 
texto, la Diputación se refería a "la situación de este cuerpo, sus limitadas facultades y el estado de imposibilidad en que me crehía, si los asumptos que debian resolverse" en Bayona "trascendian a variar la Constitución del Reyno"6. Asimismo, el 8 de junio la Diputación ya había comunicado a las nuevas autoridades francesas la necesidad de reunión de las Cortes navarras para tratar del tema de la transmisión de la corona a José Bonaparte ${ }^{7}$. Por lo tanto, la Diputación asumía la quiebra, por mor de las circunstancias, del principio básico de la imposibilidad de representación en otro cuerpo legislativo diferente del propio y se ponía en manos de las decisiones, a pesar de invocar la necesidad de refrendar cualquier cambio en las Cortes navarras, que allí pudieran tomarse.

Las actas de la propia Diputación no son de utilidad para conocer las posturas de dicho órgano a lo largo del mes de junio porque no se registró ninguna reunión de la misma entre el 4 de junio y la siguiente, el 1 de julio. Con todo, hemos podido comprobar la vigencia de las reivindicaciones expresadas, relativas a la necesidad por parte de la Diputación navarra de hacer constar ante Napoleón la obligación de respeto de los parámetros constitucionales propios navarros, en la correspondencia mantenida con los dos delegados navarros, documentación conservada en una carpeta del fondo de Guerra de la sección de Reino del Archivo Real y General de Navarra ${ }^{8}$. De esta forma, en carta fechada el 25 de junio, en respuesta a una del dia anterior de los delegados Escudero y Gaínza en la que éstos habían escrito a la Diputación sobre la conveniencia de "reclamar del Emperador la justicia de la constitución peculiar de V. Y., pedir su conservación, y la congregación de las Cortes", la Diputación navarra contestaba positivamente, expresando que era "justísimo el medio de reclamar de la generosidad del Emperador la observancia de la Constitución del Reino, y el pedir la congregación de los Estados en Cortes Generales" porque aquéllos sabían hasta dónde alcanzaban los poderes de la Diputación y porque "las Cortes solas son las que deven intervenir en cosa granada". Con anterioridad, el 19 de junio los dos comisionados habian recibido una descripción, que habian solicitado el día 14 y que la Diputación remitió el 17, sobre la Constitución de Navarra, obra con toda seguridad del síndico Alejandro Dolarea, en la que ésta era descrita en clave paraliberal según los moldes de la "monarquía templada" y de la separación de poderes tomados de Montesquieu9 ${ }^{9}$.

partidario de los franceses" (I. Estornés Zubizarreta, "Un informe francés sobre Navarra (1808)", Príncipe de Viana, 186, 1989, p. 218).

6 ARGN, Sección de Reino, Guerra, Legajo 15, Carpeta 4: Exposición de 10 de junio de 1808 del Reino.

7 ARGN, Sección de Reino, Casamientos, muertes de reyes y sucesión a la Corona, legajo 4, carpeta 43: Contestación de la Diputación en torno a la abdicación de la Corona de España y su transmisión a José Bonaparte.

8 ARGN, Sección de Reino, Guerra, Legajo 15, Carpeta 7: Comunicación de la Diputación del Reino con don Miguel Escudero y don Luis Gainza sus diputados en la Junta de Notables de Bayona, acerca de las sesiones de ésta, esplicaciones de Napoleón, nueva constitución que se preparaba para España, y solicitud de que se conservase la de Navarra (junio-julio de 1808). De forma llamativa, nadie que sepamos había hecho hasta ahora mención del contenido de esas cartas.

9 Ibidem. Fernando Mikelarena Peña, "Discursos en torno a la Constitución Histórica de Navarra hasta 1813. Origen del concepto y adaptaciones a un contexto cambiante", Iura vasconiae: revista de derecho histórico y autonómico de Vasconia, 8, 2011, pp. 126-129. 
De hecho, las reivindicaciones expresadas se siguen mencionando en la Representación presentada por los delegados Escudero y Gaínza con fecha de 24 de junio, y que, según una carta de ellos mismos del día 27, fue entregada a Azanza, presidente de la Asamblea, conjuntamente con el mencionado documento de descripción de la constitución de Navarra. En dicha Exposición se reconocía la ruptura que suponía la presencia de representantes de la Diputación navarra, órgano de representación permanente de las Cortes propias, en un foro unitario, y se remarcaba que el legislativo navarro había sido del todo punto soslayado, apuntándose, asimismo, a la necesidad de que las Cortes navarras fueran convocadas para ratificar las modificaciones implícitas en el Estatuto bayonés. Tras recordarse que "después de la enunciada incorporación a Castilla son repetidas las leyes, que los atestiguan garantiendo a Navarra como pacto fundamental de que sus Reyes, salva su real clemencia, no pueden hacer hechos granados ni leyes, sino a pedimento de sus tres estados, que componen sus Cortes", y que "su Diputación es el custodio de la observancia de las Leyes", los dos delegados navarros señalaban los cambios que para el ordenamiento politicojurídicoinstitucional de su reino conllevaba el "Estatuto constitucional" que se planteaba en Bayona "para toda España": "se deroga la mencionada constitución Navarra, no distinguiéndola en la generalidad de las demás Provincias, ni reconociéndose sus Cortes particulares; asimismo en cuanto se ordena por el art. 87, que la España se gobernará por un solo Código de leyes civiles; por el 103 que las aduanas serán trasladadas a la frontera de tierra y mar, y por el 104, que el sistema de contribuciones será igual en todo el Reino". No obstante, la Representación terminaba solicitando, no sólo "la congregación de las Cortes de Navarra" por estar la Diputación navarra "ceñida en los estrechos limites de su poder, que recivió de los Estados, (...) y que la imposibilitan, y a sus representantes de aspirar a otro medio", sino también "que se conserve a Navarra su constitución particular", algo del todo punto imposible según los artículos mencionados más arriba y que apuntaban a una unificación en todos los ámbitos ${ }^{10}$.

La centralidad de la solicitud navarra, al remarcar la nuclearidad de las Cortes navarras en relación con el ordenamiento constitucional propio, figuraba en otro documento: en una carta del 27 de junio Escudero y Gaínza informaban a la Diputación que habian anotado diversas observaciones en una copia del estatuto constitucional que se les había entregado, "añadiendo en el artículo de las Cortes, que devía tener excepción por lo respectivo a ese reino; porque goza el fuero imemorial de establecerse sus Leyes en cortes particulares suias conforme a su constitución establecida en el origen mismo de la Monarquía, como consta del

10 La representación de los dos comisionados de la diputación navarra data del 24 de junio y puede verse en Actas de la Diputación general de españoles que se juntó en Bayona el 15 de junio de 1808, en virtud de la convocatoria expedida por el Gran Duque de Berg, como lugarteniente general del reino, y la Junta Suprema del Gobierno, con fecha 19 de Mayo del mismo año, precedidas de dicha orden convocatoria y los poderes y órdenes que presentaron los que asistieron a ella, y seguidas del proyecto de Constitución consultado por el Emperador a la misma; las observaciones más notables que sobre aquel proyecto se produjeron, y la Constitución definitivamente hecha, que fue aceptada por la misma Diputación general en 7 de julio del propio año, Madrid, Imprenta de J. García, 1874, p. 106. 
Código del Fuero, y en su consequencia nunca han concurrido a las Cortes de Castilla los Navarros"11.

Como es sabido, la Exposición navarra era coincidente con las Exposiciones que realizaron los comisionados de las tres Provincias Vascongadas ${ }^{12}$ en el sentido de defender el carácter pactado de la Constitución histórica de los distintos territorios y de remarcarse que diversos aspectos de la foralidad quedaban afectados por el nuevo sistema constitucional, entre ellos el hecho de desconocerse las asambleas propias y la subsiguiente pérdida de la independencia y de la soberanía, la imposición de un Código Civil único y de una jurisdicción única anuladora de la jurisdicción propia, la supresión de las Aduanas entre las provincias y el resto de la Monarquía y el establecimiento de un sistema de contribuciones uniforme. También los representantes de los cuatro territorios coincidian en solicitar a Napoleón el mantenimiento de la Constitución tradicional o ser eximidos del régimen constitucional. ${ }^{13}$

Se ha sostenido que dichas exposiciones demostraban "una mentalidad y una forma de concebir la politica absolutamente tradicionales, en la que no se reconoce la validez de ningún cuerpo intermedio entre la Provincia y el Rey, de quien emana el poder y que es su depositario absoluto (...)". Desde ese punto de vista, para dichos territorios, "el Rey era el único poder supremo reconocido" y el que concedía la Constitución, razón por la cual los representantes vasconavarros decidieran "recurrir directamente a él -encarnado entonces en la persona de José Bonaparte- y no a la Asamblea para solicitar el mantenimiento de los fueros", imitando con esa estrategia la conducta tradicional de las autoridades forales de acudir al monarca español, evitando así confrontar con el conjunto de la asamblea que, en opinión del diputado vizcaíno Yandiola, estaría radicalmente en contra de las aspiraciones vasconavarras de mantenimiento del régimen diferenciado de los cuatro territorios ${ }^{14}$. Sin embargo, hay que tener en cuenta la importancia de las mediaciones personales en la tramitación del texto constitucional bayonés por cuanto éste "no fue el resultado de una deliberación y menos aún la expresión de la voluntad de unos representantes de la nación española, por más que hubiese algún asomo de debates en algunas de las sesiones de la misma, y aunque también se diesen votaciones relativamente a

11 ARGN, Reino, Sección de Guerra, Legajo 15, Carpeta 7: Comunicación de la Diputación del Reino con don Miguel Escudero y don Luis Gainza sus diputados en la Junta de Notables de Bayona, acerca de las sesiones de ésta, esplicaciones de Napoleón, nueva constitución que se preparaba para España, y solicitud de que se conservase la de Navarra (junio-julio de 1808).

${ }^{12}$ La exposición del representante de la diputación alavesa tiene la fecha del 22 de junio; la del de la guipuzcoana, también del 24; y la del de la vizcaína, del 25. Figuran en Actas de la Diputación general de españoles que se juntó en Bayona el 15 de junio de 1808, en virtud de la convocatoria expedida por el Gran Duque de Berg, como lugarteniente general del reino, y la Junta Suprema del Gobierno, con fecha 19 de Mayo del mismo año, precedidas de dicha orden convocatoria y los poderes y órdenes que presentaron los que asistieron a ella, y seguidas del proyecto de Constitución consultado por el Emperador a la misma; las observaciones más notables que sobre aquel proyecto se produjeron, y la Constitución definitivamente hecha, que fue aceptada por la misma Diputación general en 7 de julio del propio año, op. cit., pp. 106-110.

13 Gregorio Monreal Zia, "Los fueros vascos en la Junta de Bayona de 1808", Revista Internacional de Estudios Vascos, Cuadernos, 4, 2009, pp. 266-272.

14 Gregorio Monreal Zia, “Los fueros vascos en la Junta de Bayona de 1808”, op. cit., p. 273; Coro Rubio Pobes, Revolución y tradición. El Pais Vasco ante la revolución liberal y la construcción del Estado Español, 1808-1868, Madrid, Siglo XXI, 1996, p. 131. 
algunos puntos expresados en el texto sometido a examen" y que "en todo caso, los diputados de Bayona pudieron expresar moderadamente sus votos y opiniones a fin de que sirvieran de consulta a quien, en definitiva, era el que debía decretar el citado Estatuto para España, que no era otro sino el propio Napoleón"15. Obviamente, considerando el precedente de los bajonavarros en 1789, que evidenciaría las pocas probabilidades de éxito de una reivindicación de mantenimiento del status de autogobierno, hasta entonces existente, en un foro parlamentario de sensibilidad mayoritariamente liberal proclive a la nivelación territorial, esa estrategia se revelaría como la única baza a jugar, máxime en el caso de que se detectara receptividad en la cúspide del poder napoleónico.

Las peticiones de las cuatro provincias forales contaron con la simpatía relativa de Napoleón. Ante el anuncio, en la sesión novena de la Asamblea el día 27 de junio de 1808, por parte de la Presidencia de la misma del inicio de las votaciones de las observaciones presentadas por los delegados, Yandiola, diputado por Vizcaya, alegó "que por parte de su principal había hecho representación directamente a S. M. el Emperador, pidiendo la conservación de los fueros y constitución particular del señorío [de Vizcaya], y lo exponía, o protestaba, en caso necesario, para que su asistencia y participación en este acto no se tuviera por adhesión a la constitución general, y que en caso necesario se abstendría de votar". La respuesta de la Presidencia no fue de rechazo, sino que manifestó que "no había inconveniente en admitir y que constase en el Acta su exposición". Seguidamente, ante ello, los representantes "del reino de Navarra y de las dos provincias de Guipúzcoa y Álava" hicieron lo mismo. El reconocimiento formal a las constituciones históricas de los cuatro territorios por parte de la Presidencia se confirma por otro hecho: a continuación, ante la pretensión del diputado José Garriga de "hacer otra igual [alegación] por el Principado de Cataluña", la Presidencia "le hizo observar que ni habia sido nombrado por el Principado mismo, que era el caso de los otros Diputados, ni la Cataluña tenía una Constitución particular". Con todo, tras la lectura por parte de Yandiola de la "exposición y protesta" mencionada, los diputados de la ciudad de Burgos "contraprotestaron en nombre de Castilla"16.

15 Juan Mercader Riba, José Bonaparte Rey de España. 1808-1813. Estructura del Estado español bonapartista, Madrid, CSIC, 1983, p. 23. De cualquier forma, en el último momento, por razones de mantenimiento de formas, Napoleón decidió que fuera José I el que figurara como otorgador de la constitución (Ibid., p. 24). En su correspondencia con la Diputación vizcaína Yandiola expresó el 26 de junio, comentando el proyecto de Constitución, que "no reconozco en ella [la Junta] ni en la Nación autoridad para derogar nuestra constitución. (...) si yo dirijo la representación a S. M. I. [el Emperador Napoleón Bonaparte] es porque él es quien da la Constitución". Citado en Gregorio Monreal Zia, "Los fueros vascos en la Junta de Bayona de 1808", op. cit., pp. 261-263.

16 Actas de la Diputación general de españoles que se juntó en Bayona el 15 de junio de 1808, en virtud de la convocatoria expedida por el Gran Duque de Berg, como lugarteniente general del reino, y la Junta Suprema del Gobierno, con fecha 19 de Mayo del mismo año, precedidas de dicha orden convocatoria $y$ los poderes $y$ órdenes que presentaron los que asistieron a ella, y seguidas del proyecto de Constitución consultado por el Emperador a la misma; las observaciones más notables que sobre aquel proyecto se produjeron, y la Constitución definitivamente hecha, que fue aceptada por la misma Diputación general en 7 de julio del propio año, op. cit., p. 37. Sobre ese episodio, los representantes navarros decian en carta fechada el 1 de julio de 1808: "En 26 del pasado incluímos a V. Y. copia de nuestra representación al emperador en favor de la constitución de V. Y. en que indicamos lo mismo, que nos tenía encargado". Asimismo, añadian que, "al tratarse en la Junta de deliberar sobre las observaciones hechas acerca del estatuto por algunos de sus 
El desenlace final de la cuestión no se advino, en sentido estricto, a las solicitudes de los cuatro territorios forales de rechazo a la desaparición de sus propias asambleas y órdenes constitucionales, y de convocatoria, en el caso de Navarra, de las Cortes propias para abordar cualquier modificación. Después de no figurar en absoluto ninguna mención a los fueros de Navarra y Vascongadas ni en los anteproyectos preliminares debatidos por expertos antes de la reunión bayonesa ni en el proyecto presentado a la asamblea ${ }^{17}$, el texto final, en su artículo 144, hablaba de que aquéllos se examinarian "en las primeras Cortes para determinar lo que se juzgue más conveniente al interés de las demás provincias y al de la nación". Puede estimarse que ese desenlace, filtrado con anterioridad al menos al representante vizcaíno y a los representantes navarros ${ }^{18}$,

Individuos, pedimos no parasen perjuicio a la constitución de V. Y. sobre cuia guarda teníamos representado a S. M. I. y lo mismo hicieron las Provincias exentas; contraprotestó la ciudad de Burgos a nombre de Castilla, y estamos pendientes de lo que sobrevenga hasta que se nos haga saber la constitución" [ARGN, Reino, Sección de Guerra, Legajo 15, Carpeta 7: Comunicación de la Diputación del Reino con don Miguel Escudero y don Luis Gainza sus diputados en la Junta de Notables de Bayona, acerca de las sesiones de ésta, esplicaciones de Napoleón, nueva constitución que se preparaba para España, y solicitud de que se conservase la de Navarra (junio-julio de 1808).]. Asimismo, el representante de la Diputación de Vizcaya, Yandiola, en su correspondencia con aquélla expresará sobre dicho episodio: "Procedemos de acuerdo los Diputados de Guipúzcoa, Álava y Reino de Navarra y yo, y cada uno ha formado una Representación, absteniéndonos de hacer en Junta la más leve observación, como acaso podriamos, sobre los diversos puntos de la Constitución, para que no se nos atribuya en tiempo alguno que prestamos nuestro consentimiento". Citado en Citado en Gregorio Monreal Zia, "Los fueros vascos en la Junta de Bayona de 1808", op. cit., pp. 261-263.

17 Los anteproyectos preliminares se pueden ver en Carlos Sanz Cid, La Constitución de Bayona. Labor de redacción y elementos que a ella fueron aportados, según los documentos que se guardan en los Archives Nationales de Paris y los Papeles Reservados de la Biblioteca del Real Palacio de Madrid, op. cit., pp. 174-202, pp. 233-252 y pp. 260-307. El texto debatido en la asamblea tras ser presentado en la misma el 20 de junio y el texto final del 7 de julio, en Actas de la Diputación general de españoles que se juntó en Bayona el 15 de junio de 1808, en virtud de la convocatoria expedida por el Gran Duque de Berg, como lugarteniente general del reino, y la Junta Suprema del Gobierno, con fecha 19 de Mayo del mismo año, precedidas de dicha orden convocatoria y los poderes y órdenes que presentaron los que asistieron a ella, y seguidas del proyecto de Constitución consultado por el Emperador a la misma; las observaciones más notables que sobre aquel proyecto se produjeron, y la Constitución definitivamente hecha, que fue aceptada por la misma Diputación general en 7 de julio del propio año, op. cit., pp. 51-60 y pp. 119-128.

18 Tras valorar la Diputación positivamente el 2 de julio las gestiones hechas hasta la fecha por los dos representantes, reconociendo que era "lo único que en tales circunstancias se podía practicar", el 4 de julio Gaínza y Escudero comunicaban a la Diputación que Urquijo les había asegurado "haver interesado a S. S. M. M. el Emperador y el Rey por la conservación de las constituciones particulares de V. Y. Y de las Provincias Exentas, y que no se innovaria en ellas hasta que en las primeras Cortes Generales de España se examinasen los fueros con audiencia de los países privilegiados; añadió que havía instado al Emperador para que esta disposición se insertase en la Constitución, pero que todavia no se havia resuelto sobre ello; en breve saldrán las resultas al publicarse la Constitución, que quizá alterará el Estatuto, cuio contexto interesa sin embargo" [ARGN, Reino, Sección de Guerra, Legajo 15, Carpeta 7: Comunicación de la Diputación del Reino con don Miguel Escudero y don Luis Gainza sus diputados en la Junta de Notables de Bayona, acerca de las sesiones de ésta, esplicaciones de Napoleón, nueva constitución que se preparaba para España, y solicitud de que se conservase la de Navarra (junio-julio de 1808)]. Esa última información es de una extraordinaria importancia en cuanto que avala la presunción de Monreal Zía (Gregorio Monreal Zia, "Los fueros vascos en la Junta de Bayona de 1808", op. cit., pp. 265-266), fundamentada exclusivamente en la correspondencia de Yandiola y relativa a la narración de una entrevista que mantuvo con José I el día 30, de que Urquijo desempeñó un papel absolutamente determinante de defensa de los fueros vasconavarros, filtrando de antemano cómo iba a quedar el status de las Provincias Vascongadas y de Navarra. De hecho, un mes antes 
constituía un logro en la medida en que suponía un reconocimiento de los fueros, si bien susceptibles de revisión ulterior, en un medio inicialmente desfavorable al mantenimiento de los mismos, sobre todo, si tenemos en cuenta que, al parecer, como hemos apuntado, ninguna de las versiones preliminares los consideraba. Se ha estimado que la inclusión de ese artículo fue producto de las mediaciones ante Napoleón del presidente y el secretario de la Asamblea, el navarro Azanza y el vizcaíno Urquijo respectivamente, así como de una estrategia geopolítica napoleónica ${ }^{19}$.

De cualquier manera, caben dudas sobre en qué medida las singularidades forales podian haber sido respetadas en el caso de que la monarquía josefina se hubiera mantenido en España. No hay que olvidar que el texto final de la Constitución de Bayona conformaba unas Cortes para el conjunto de la monarquía de carácter estamental cuyo tercer estado estaba integrado parcialmente por diputados de designación territorial por las provincias o por las ciudades, sin que hubiera ninguna alusión a los reinos o provincias exentas. Asimismo, se hacía tabla rasa de las diferencialidades forales en todos los órdenes. En lo que toca al orden judicial se disponia que los territorios de la monarquía se gobernarian por un solo código de leyes civiles y criminales y que la administración de justicia se fundamentaría en una planta única. Lo mismo sucedia en materia hacendística, al disponer que el sistema fiscal fuera el mismo para todo el Reino. También se suprimian las aduanas interiores entre partidos o provincias $^{20}$.

Por otra parte, dicho artículo 144, al ubicar la solución al tema foral en una asamblea legislativa formada por representantes de los territorios españoles, suponía la quiebra del principio pactista, aún cuando la apelación a la conveniencia de las provincias afectadas puede ser interpretado como el resultado de una hipotética negociación entre las diputaciones y el gobierno central que incluso podía saldarse con un resultado positivo si éste último se mostrara receptivo a las peticiones vasconavarras y pudiese obviamente condicionar la decisión de las Cortes que trataran del tema ${ }^{21}$.

Por último, en la reunión del 4 de julio, la Diputación encargó a Escudero y a Gaínza para que presentaran a José I una representación sobre su reconocimiento como rey en el plazo de cuatro dias por cuanto ese tema podía

de los sucesos que estamos describiendo, el dia 5 de junio, Urquijo habia elevado un informe al propio Napoléon, conservado en los archivos nacionales franceses, en el que se subrayaba la necesidad de tratar con deferencia los fueros de los territorios fronterizos con Francia y en el que se señalaba textualmente "Como la Constitución debe de salvar la igualdad de pesos y medidas, es bueno observar que las tres provincias de Vizcaya y el reino de Navarra son la puerta y seguridad de España, y estas provincias han sido felices porque no entraban en los bienes de mano muerta y tenían privilegios que favorecian la división de la propiedad. Si a estas provincias se las pone al nivel de las demás hay que temer alguna agitación. S. M. verá si se las puede dar alguna compensación en la Constitución"(C. Sanz Cid, C. Sanz Cid, La constitución de Bayona, Madrid, Editorial Reus, 1922, p. 474).

19 Sobre dicha estrategia napoleónica puede verse Fernando Mikelarena Peña, "La geopolitica napoleónica en relación con el País Vasco y Navarra”, Tiempos Modernos: Revista Electrónica de Hisotira Moderna, 26, 2013/1.

20 Ignacio Fernández Sarasola, La constitución de Bayona, Madrid, Iustel, 2007, pp. 189-235.

21 Gregorio Monreal Zia, "Los fueros vascos en la Junta de Bayona de 1808”, op. cit., pp. 272274. 
"rozar la Constitución" de Navarra. Dos días más tarde, los enviados notificaban que no era conveniente la presentación de la misma porque así se lo había recomendado Urquijo, el secretario de la asamblea. Por último, en la sesión de la diputación del 15 de julio se acordó hacer una nueva representación en la que se respondia a la petición de José I de ser reconocido como rey y que se enviase al mencionado Urquijo. En ese texto se hablaba de la necesidad de que el nuevo monarca jurara respetar los fueros navarros para poder ser proclamado como tal.

\section{ANTE LAS CORTES DE CÁDIZ.}

\section{La representación navarra en las Cortes de Cádiz.}

El desenlace abolitorio en relación con la constitución histórica de Navarra durante el proceso constituyente que desemboca en la Constitución gaditana, y que arranca en primerísima instancia de la constitución de la Junta Suprema Central, se vió facilitada por la extraña incapacidad de las instituciones navarras para enviar a la ciudad andaluza una representación mínimamente eficaz, siquiera de forma oficiosa dada la desaparición durante aquellos años de la Diputación legítima.

Obviamente no cabe olvidar el hecho de la disolución en abril de 1809 de la Diputación navarra surgida de las Cortes de Olite de 1801, el órgano legitimado para la adecuada defensa de la Constitución Histórica de Navarra, tal y como había sucedido en Bayona y en todas las coyunturas anteriores y posteriores en que aquélla fue objeto de debate. El 27 de agosto los miembros de aquélla se dieron a la fuga, abandonando Pamplona a instancias del alto mando español ${ }^{22}$.

22 En ARGN), Reino, Sección de Guerra, Legajo 15, Carpeta 43 se conserva una carta escrita desde Corella, sin firma, a la Diputación por Miguel Escudero, miembro de la misma, comunicándola que el conde del Montijo general del ejército de Aragón en Tudela le había dicho que era necesario que la Diputación saliese de Pamplona. Consta también la respuesta positiva de la Diputación. Mientras Miranda Rubio (Francisco Miranda Rubio, "La financiación de la guerra de la Independencia. El coste económico en Navarra", Príncipe de Viana, 2004, 233, p. 819, nota 28) dice que todos los miembros de la Diputación se fugaron de Pamplona, Egibar (Lartaun de Egibar Urrutia, "El sistema napoleónico en el espacio vasco. Del ordenamiento foral a un nuevo régimen. Implantación y alcance", Historia constitucional: Revista Electrónica de Historia Constitucional, 9, 2008, p 29) dice que fue la mayoría, pero no la totalidad. Galán Lorda (Mercedes Galán Lorda, "Navarra ante el nuevo fenómeno constitucional: el gobierno del último Reino peninsular entre 1808 y 1814", Iura vasconiae: revista de derecho histórico y autonómico de Vasconia, 2011, 8, p. 312) especifica que los miembros de la Diputación que se fugaron fueron Escudero, Balanza, Del Río y Amatria y Bellido, abad de la Oliva, así como el secretario Baset y los síndicos Lejalde, Ibáñez y Dolarea. Permanecieron en Pamplona Ilundáin, Bayona y Navascués, si bien del primero de estos tres consta su negativa a seguir en el cargo y su detención posterior. Hay que señalar que ya a principios de junio, el día 3 más exactamente, los miembros de la Diputación Fray Pascual Belio (abad de la Oliva), Joaquín Bayona y Manuel Diaz del Rio, así como el secretario de la corporación Diego Maria Basset, habian preguntado al virrey marqués de Vallesantoro sobre la conveniencia de su traslado a Lerín, recibiendo dos días después la respuesta negativa del interpelado quien consideró, dadas las críticas circunstancias, "más urgente que nunca" que aquélla permaneciera en la capital navarra (ARGN, Reino, Sección de Diputación del reino, sus sindicos y secretario, gefes políticos y diputaciones provinciales, Legajo 3, Carpeta 2: Oficio de la Diputación del Reino al virrey proponiéndole el pensamiento de trasladarse aquélla a la villa de Lerín para ejercer con más libertad sus funciones. Está la contestación desaprobando la idea). Por otra parte, el 11 de septiembre desde Ágreda los miembros fugados de la Diputación remitían una carta a los generales Cuesta y Castaños, a don Pedro Ceballos y al Duque del Infantado dándoles noticia de su salida de Pamplona por evitar la dominación francesa y contribuir a la restauración del Rey 
Por lo tanto, a finales de agosto terminarian las relaciones entre la Diputación y el ocupante francés al desmarcarse aquélla de la legalidad josefina y al establecerse de forma nómada primero en Ágreda, luego en Tarazona y, más tarde, al inicio de octubre ya, en Tudela. El 7 de noviembre esta Diputación en el exilio se dirigirá a los alcaldes navarros llamando a las armas y poniéndose en contacto con la Junta Suprema de España, jurando como rey a Fernando VII. Tras la victoria de los franceses en la batalla de Tudela el 23 de noviembre de 1808 esta Diputación resistente continuará un periplo itinerante, al principio por tierras aragonesas y riojanas ${ }^{23}$. A partir de noviembre de 1808 aparecerán como miembros de la misma solamente los diputados Francisco Belío (abad de La Oliva), Miguel Escudero y Manuel Diaz del Río, junto con el secretario Basset y algún o algunos sindicos ${ }^{24}$. Aunque se ha hablado de que su autodisolución definitiva fue el 13 de abril de 1809 en Arnedo, el documento en que se ha basado esa información es muy poco concluyente a ese respecto ${ }^{25}$. Hay que decir que las actas de la Diputación del Reino propiamente dichas acaban el 27 de agosto de 1808, no teniendo nada que ver las de los meses inmediatamente anteriores con las actas habituales a causa de su carácter telegráfico, carácter que se repetirá en las instituciones de naturaleza administrativa que instaurarán los franceses ${ }^{26}$.

Don Fernando $7^{\circ}$ en el Trono (ARGN, Reino, Sección de Diputación del reino, sus sindicos y secretario, gefes políticos y diputaciones provinciales, Legajo 3, Carpeta 3).

23 Francisco Miranda Rubio, "La quiebra del régimen foral navarro bajo la ocupación francesa (1808-1814)", Príncipe de Viana, 235, 2005, pp. 454-458.

${ }^{24}$ El 25 de noviembre de 1808 la Diputación estaba en el Santuario de Sancho Abarca, cerca de Tauste; al principio de diciembre, en Huesca; el 18 de diciembre de 1808, en Arnedo (Francisco Miranda Rubio, "La quiebra del régimen foral navarro bajo la ocupación francesa (1808-1814)", op. cit., pp. 454-458; Lartaun de Egibar Urrutia, "El sistema napoleónico en el espacio vasco. Del ordenamiento foral a un nuevo régimen. Implantación y alcance", op. cit.; Jean Baptiste Busaall, "Constitución histórica y revolución liberal: el reino de Navarra, ¿un modelo posible para la reforma institucional en las Cortes de Cádiz?", en Jean Baptiste Busaall y Lartaun de Egibar Urrutia, Las instituciones del Reino de Navarra en el debate histórico jurídico de la revolución liberal, Pamplona, Universidad Pública de Navarra, 2005, p. 77; Francisco Miranda Rubio, La Guerra de la Independencia en Navarra. La acción del Estado, Pamplona, Institución Príncipe de Viana, CSIC, 1977, pp. 332-338). En esta última referencia se transcriben las cartas de la Diputación fechadas en Tudela en 13 de octubre de 1808, en Tauste en 25 de noviembre de 1808, en Huesca en 4 de diciembre de 1808 y en Arnedo en 13 de abril de 1809.

${ }^{25}$ Francisco Miranda Rubio, La Guerra de la Independencia en Navarra. La acción del Estado, op. cit., p. 65. La carta en la que se basa la afirmación en Ibid., pp. 337-338. La firmaban únicamente tres miembros de la Diputación: el abad de la Oliva, Miguel Escudero y Manuel Diaz del Río, apareciendo también el síndico Francisco Ibáñez.

${ }^{26}$ En la portada del tomo 29 de las Actas de la Diputación del Reino figura significativamente los siguiente: "Actas de la Diputación del Reino, desde 30 de setiembre de 1805 hasta 27 de agosto de 1808 en que la diputación legitima se salió de Pamplona huyendo de la dominación francesa; $y$ desde 10 de agosto de 1810, en que el General francés Conde Reille, creó una nueva Diputación, que después en 13 de abril de 1812 se convirtió en Consejo de Yntendencia, hasta 23 de junio de 1813". El siguiente libro de actas va del 28 de mayo de 1814 al 20 de diciembre de 1816 . Hay que decir que, por efecto de los decretos de febrero de 1810, el gobernador militar Dufour, llegado a Pamplona justamente aquel mismo mes, creará diversas instituciones totalmente nuevas y sin ningún entronque con las instituciones forales anteriores, entre ellas un Consejo de Gobierno compuesto por una quincena de miembros y estructurado en tres secciones, la de Hacienda, la de Justicia y Negocios Eclesiásticos y la de Interior. Pasados unos meses, el 4 de agosto de 1810, el general Reille anuló el Consejo de Gobierno formado en marzo del mismo año e instituyó el día 10 de ese mes una Diputación formada por un representante de cada merindad más un 
No obstante, a pesar de su carácter itinerante y de no ser propiamente dicha una Junta Suprema Provincial, la Diputación navarra consiguió incorporar a mediados de octubre de 1808, como premio a su rechazo de la legalidad josefina al abandonar Pamplona a finales de agosto de aquel año, a dos de sus miembros, Miguel de Valanza y Carlos de Amatria, como representantes suyos en la Junta Suprema Central y Gubernativa del Reino ${ }^{27}$, lo que indicaría que existian vías alternativas para estar presente en los ámbitos decisorios. Como es sabido, dicha Junta Suprema Central fue el órgano que acumuló los poderes ejecutivo y legislativo españoles durante la ocupación napoleónica de España y la ausencia del rey Fernando VII, constituyéndose con 35 delegados de las Juntas Provinciales bajo la presidencia del conde de Floridablanca tras la victoria en la batalla de Bailén y después de que el Consejo de Castilla declarase nulas las abdicaciones de Bayona, estando vigente hasta el 30 de enero de 1810, fecha ésta en que se creó el Consejo de Regencia de España e Indias. Con todo, no parece que Valanza y Amatria desempeñaran ningún papel significativo en el seno de la misma, a pesar de formar parte de algunas comisiones ${ }^{28}$.

De forma llamativa, esos dos comisionados carecieron de cualquier operatividad a la hora de canalizar el proceso de elección de representantes de Navarra en la reunión gaditana. En un primer momento Valanza y Amatria dirigieron, de acuerdo con el decreto de 28 de octubre de 1809, expedido por la Junta Suprema gubernativa del Reino, por el que se anunciaba la celebración de Cortes que se convocarian el 1 de enero de 1810 y que se reunirian a partir de marzo inicialmente en Sevilla, un oficio a la Diputación (funcionalmente extinguida, pero, por lo visto, nominalmente subsistente) en noviembre en el que transmitian otro de la Comisión de Cortes en el que se solicitaban datos sobre los navarros que podrian ser diputados, contestando en un primer momento aquélla que no podia proporcionar ninguna lista por estar desconectada del territorio

representante de los comerciantes navarros. Reille, por tanto, instauró una Diputación nueva, conservando "el nombre antiguo para mitigar el contraste y hacer un nuevo sistema familiar". Reille fijó las atribuciones de la Diputación en un decreto en el que 10 de sus 11 artículos hablaban de su función recaudadora, revalidando en el penúltimo todas las demás atribuciones que tenía la antigua Diputación del Reino. Además de que sus funciones eran menores, la capacidad administrativa y fiscal de esa Diputación quedaba subordinada al gobernador militar. La Diputación instituída por Reille en agosto de 1810 estaba formada por seis miembros designados por el general francés y La presidencia recaería sobre Joaquín Bayona, antiguo y único miembro de la antigua Diputación en esta nueva, si bien sería apresado y deportado a Francia en noviembre. A principios de 1812 el sustituto de Reille, el general Abbé, sustituyó la Diputación instaurada por aquél por un Consejo de Intendencia, cuyas funciones eran similares a las de aquél órgano (Cfr. Francisco Miranda Rubio, "La quiebra del régimen foral navarro bajo la ocupación francesa (1808-1814)", op. cit., pp. 460-463; Rodrigo Rodriguez Garraza, Navarra de reino a provincia (1828-1841), Pamplona, Eunsa/Institución Príncipe de Viana, 1968, pp. 32-33; Hermilio de Olóriz, Navarra en la guerra de la independencia; biografia del guerrillero D. Francisco Espoz (Espoz y Mina), y noticia de la abolición y restablecimiento del régimen foral, Pamplona, 1910, p. 61).

27 ARGN, Reino, Sección de Diputación del Reino, sus Síndicos y Secretario, Gefes políticos y Diputaciones Provinciales, Legajo 3, Carpeta 5. La incorporación de dichos dos miembros no se hizo desde el inicio de la constitución de dicha Junta Suprema Central el 25 de septiembre de 1808 por no haber sido suficiente el poder expedido a su favor por la Diputación, que tuvo que ser ampliado en un segundo aval.

28 Gregorio Monreal Zia, "Los diputados vascos y navarros (El Reino de Navarra y las Provincias Vascongadas en las Cortes y en la Constitución de Cádiz)", en Juan Antonio Escudero (Coord.), Cortes y Constitución de Cádiz: 200 años, Madrid, Espasa, 2011, v. 1, op. cit., p. 355. 
navarro ${ }^{29}$. No obstante, posteriormente, en respuesta a esa petición se elaboraron varias listas por dos conductos diferentes. Por un lado, el obispo de Pamplona, Veremundo Arias Teixeiro, remitió una relación fechada el 31 de diciembre de 1809 en la que se relacionaban numerosos eclesiásticos navarros con destinos en otras provincias; por otro lado, los mismos Valanza y Amatria confeccionaron dos listados: uno que incluía a los navarros que podian ser dignos representantes del reino y otro con el de los individuos que se encontraban fuera del reino ${ }^{30}$. De cualquier forma, esos intentos se vieron truncados por la marcha de los acontecimientos, por el estado de ocupación del territorio navarro y por las instrucciones que se fijaron para el proceso electoral de representantes.

Tras la promulgación de la Instrucción que debía observarse para la elección de Diputados de Cortes de 1 de enero de 1810, según la cual se podían elegir diputados de tres formas ${ }^{31}$, Navarra podía enviar representantes en virtud de lo fijado en el capítulo primero de la mencionada instrucción, careciendo de legitimidad para servirse del canal abierto por los capitulos quinto y sexto porque no existía Junta Suprema Provincial y porque ninguna ciudad navarra participó en las Cortes de 1789, Cortes a las que asistieron ciudades del Reino de Castilla y de los territorios de la Corona de Aragón. Con todo, el 23 de agosto de 1810, los exmiembros de la desaparecida hace algunos meses Junta Suprema Central Valanza y Amatria, junto con los síndicos del reino Lejalde y Dolarea, también en tierras andaluzas, elevaron una solicitud a la Regencia para que ésta considerara, por efecto de la pertenencia registrada de aquellos dos exdiputados del reino a aquella Junta Suprema, el reconocimiento de la Diputación de Navarra como Junta Superior de Observación de cara a poder designar la misma, en consecuencia, un diputado, elección que correría por cuenta de los cuatro firmantes. Esa petición habría contado con el visto bueno de la Regencia, pero no consiguió el respaldo de las Cortes $^{32}$. La negativa final no fue coherente con el

29 ARGN, Reino, Sección de Diputación del Reino, sus Síndicos y Secretario, Gefes politicos y Diputaciones Provinciales, Legajo 3, Carpeta 5.

30 José Ramón Urquijo Goitia, "Vascos y navarros ante la Constitución: Bayona y Cádiz”, en AAVV, Vascos en 1808-1813. Años de guerra y Constitución, Madrid, Biblioteca Nueva, 2010, p. 173.

31 En primer lugar, según el artículo 8 del capítulo primero de la mencionada Instrucción, se elegian diputados por cada una de las 33 circunscripciones provinciales diferenciadas en el territorio peninsular e insular próximo, considerándose al reino de Navarra como una distrito provincial más, en número de uno por cada 50.000 habitantes contabilizados en el último censo realizado, el denominado censo de Godoy de 1797. Según el artículo 10 de ese mismo capítulo primero, correspondian a Navarra 4 diputados. Además, se establecía un procedimiento único de elección de carácter indirecto a través de varios niveles. En segundo lugar, según el artículo 1 del capítulo quinto de la misma instrucción, cada una de las Juntas Superiores de Observación y Defensa (que es el nombre que asumieron las Juntas Supremas Provinciales a partir de un momento dado) podía nombrar un diputado, especificándose en el artículo 2 de ese capítulo que se seguiría el mismo procedimiento adoptado en el capitulo primero. En tercer lugar, el artículo primero del capitulo sexto hablaba de que, además, las ciudades que habian enviado diputados a las últimas Cortes celebradas en el año de 1789 tendrian el derecho de enviar también un representante ahora. Esas ciudades eran 37, 16 de ellas de los territorios de la Corona de Aragón, aunque al final eligieron representantes para la reunión gaditana 28 (Pilar Chávarri Sidera, Las elecciones de Diputados a las Cortes Generales y Extraodinarias (1810-1813), Madrid, Centro de Estudios Constitucionales, 1988, p. 7, 24 y 69-70).

32 José Ramón Urquijo Goitia, "Vascos y navarros ante la Constitución: Bayona y Cádiz", op. cit., pp. 173-174. 
hecho de que se permitiera elegir diputados a algunas Juntas Provinciales que no habian estado ni siquiera como invitadas a posteriori, caso de Navarra, en la Junta Central tras la conformación de ésta (como las de Cádiz, Cuenca, Guadalajara, Molina de Aragón, la Rioja-Álava y Santander). Mucho menos lo fue con la circunstancia de que, entre las que se han mencionado, finalmente se les diera finalmente el acta parlamentaria a los diputados elegidos en algunas de ellas (como a los de Cádiz y Molina) ${ }^{33}$.

Asimismo, los mismos firmantes, con la salvedad de Amatria, reemplazado por Juan Bautista Mencos, pidieron también en otro memorial que la Regencia concediera derecho de asistencia y de representación en Cortes a las ciudades navarras cabezas de merindad (esto es, Pamplona, Estella, Olite, Sangüesa y Tudela). En este caso, la Regencia admitió a Pamplona, pero el acuerdo no llegó a publicarse $^{34}$.

El fallido intento de esas personalidades ligadas a las instituciones navarras de incrementar la representación navarra en Cádiz mediante la primera vía alternativa que proponía la instrucción de enero de 1810, realizando un ejercicio de equiparación de la Diputación con una Junta Suprema Provincial navarra inexistente en virtud de la presencia en la Junta Suprema Central Gubernativa de dos miembros de aquélla gracias a la generosidad mostrada en esa ocasión por ésta en cuanto a su admisión, entronca en cierta forma con la petición de un alavés, representante de la Diputación foral alavesa, llamado Trifón Ortiz de Pinedo, que, ante la Comisión de poderes de las Cortes, reclamó infructuosamente su condición de representante de Álava, y la anulación subsiguiente del acta del diputado suplente designado en Cádiz por una veintena de alaveses que se hallaban en aquella ciudad ${ }^{35}$. Tanto en un caso como en el otro la Comisión de Poderes aducirá la incompatibilidad del nuevo orden conceptual constituyente, fundamentado en la representación nacional, que suponían las nuevas Cortes inauguradas en Cádiz en 24 de septiembre de 1810, con el orden antiguo, basado en los cuerpos territoriales, tal y como señalará el primer acuerdo de las Cortes tras su constitución y que afirmaba que los diputados reunidos en las Cortes generales y extraordinarias gaditanas representaban a la Nación española, residiendo en ellas la soberanía nacional. La falta de receptividad mostrada por las Cortes gaditanas en esa cuestión, tanto a la petición navarra como a la alavesa, supondría un preludio de la abolición de la constitución navarra que de hecho hacía la carta magna aprobada el 19 de marzo de 1812 y de la respuesta negativa que en agosto de 1813 obtuvo una solicitud que trataba de conciliar, formalmente al menos, ambas legitimidades constitucionales.

Por otra parte, en lo que respecta a la elección de diputados con arreglo al capítulo primero de la instrucción mencionada, tal proceso electoral no pudo acometerse en Navarra a causa de encontrarse ocupado nuestro territorio, viéndose afectado, por consiguiente, por el decreto de 8 de septiembre de 1810

33 Pilar Chávarri Sidera, Las elecciones de Diputados a las Cortes Generales y Extraodinarias (1810-1813), op. cit., p. 64.

34 José Ramón Urquijo Goitia, "Vascos y navarros ante la Constitución: Bayona y Cádiz”, op. cit., p. 174.

35 Bartolomé Clavero, "Constitución en común entre cultura y escritura: encrucijada gaditana de los fueros vascos", Notitia vasconiae: revista de derecho histórico de Vasconia, 2, 2003, p. 627. 
que fijaba "el número de Diputados suplentes de las dos Américas y de las provincias ocupadas por el enemigo", y que dictaba reglas para esta elección y en cuya exposición de motivos se reconocía las dificultades para llevar a cabo aquel proceso en dichas provincias. En la misma exposición de motivos se decía que, habiendo llegado hasta el momento solamente cuarenta diputados propietarios elegidos en sus circunscripciones y aunque se esperaba que llegaran "de un día a otro de los puertos de Levante un número algo considerable", existía el inconveniente de que nada menos que veintitrés provincias no podían enviar representantes por su condición de ocupadas, por lo que debía arbitrarse un sistema para el que la elección de diputados suplentes de dichas provincias en las únicas zonas en que dicha elección podía ser posible (esto es, en las zonas liberadas, a la sazón en aquel momento limitadas al enclave gaditano), no se saldase con un resultado por el que la suma de dichos diputados suplentes excediese al de diputados propietarios. Por consiguiente, en dicho decreto se asignaba a Navarra, al igual que a otras tres provincias, entre ellas las Vascongadas, un diputado suplente a elegir por "los emigrados naturales ó vecinos" de Navarra que residian en Cádiz y en la isla de León. Para poder ser elector o elegido se requerían "las calidades de mayor de veinticinco años, cabeza de casa, soltero, casado, viudo ó eclesiástico secular, de buena opinión y fama, exento de crimenes y reatos, que no haya sido fallido, ni sea deudor á los fondos públicos, ni en la actualidad doméstico asalariado de cuerpo ó persona particular". Tendrian voto y podrian "ser electores todos los concurrentes naturales ó vecinos de las referidas provincias"; pero para ser elegidos Diputados en Cortes habian "de ser naturales de los residentes en Cádiz y la isla de León, ó en cualquiera de nuestros pueblos libres". De esta manera, serían veintitrés los diputados que representarian a las provincias peninsulares ocupadas por los franceses, representando simultáneamente a las provincias y a las ciudades con voto en Cortes, en el caso de que en aquéllas hubiera de éstas últimas, y así "incorporados á los propietarios existentes y prontos á llegar", componian "un Congreso respetable, y el bastante en las circunstancias del dia para abrir las Cortes y celebrarlas sin grandes inconvenientes, aun cuando por desgracia no viniesen otros". El mismo sistema se arbitraba para las provincias de ultramar que se quedaban con treinta diputados suplentes ${ }^{36}$.

Finalmente, el 21 de septiembre de 1810 cuarenta y cuatro navarros presentes en Cádiz eligieron a los siete compromisarios que elegirian al día siguiente al diputado suplente por Navarra. Esos siete electores eran, además de los sindicos Alejandro Dolarea y Manuel Elejalde, el conde de Cimera, el ministro de la Audiencia de Navarra Francisco Izco y los militares Juan Bautista Mencos, José Armendáriz y Martín García Loygorri. Cuatro de ellos eran vecinos de Pamplona, Cimera y Armendáriz residian en Madrid y García Loygorri vivia en su localidad natal, Corella. Sea como sea, es importante reseñar la presencia en Cádiz de los dos síndicos del Reino y de personas tan cualificadas como el anteriormnete citado Mencos, así como de Cimera y de Armendáriz. A pesar de todo, al día siguiente los navarros en Cádiz eligieron a Francisco de Paula

\footnotetext{
36 Pueden verse las dos disposiciones referenciadas en la dirección http://humanidades.cchs.csic.es/ih/paginas/jrug/elecciones/index_ley.htm
} 
Escudero, Oficial de la Secretaría de Marina, como diputado suplente por Navarra ${ }^{37}$.

A pesar de que no se suele mencionar, Francisco de Paula Escudero y Ramirez de Arellano (nacido en Corella en 1764 y fallecido en Madrid en 1831) era hermano de Miguel Escudero Ramirez de Arellano (1760-1831)38, uno de los miembros de la Diputación del Reino hasta 1808 y uno de los tres de ella (junto con el abad de la Oliva y Manuel Díaz del Río) que persistieron en la Diputación nómada por tierras aragonesas y riojanas entre agosto de 1808 y abril de 1809 . También fue uno de los dos, como se recordará, representantes de tal órgano en la asamblea de Bayona de 1808. Como veremos más adelante, Miguel Escudero solicitará en vano en agosto de 1813, junto con otros tres miembros de la Diputación existente hasta 1808, la convocatoria de las Cortes de Navarra con el fin de publicar y jurar la Constitución, imitando lo que habian hecho previamente las Juntas Generales de Vascongadas a requerimiento de las Cortes Españolas y a imitación de lo que se solicitaba en la representación presentada en Bayona. Asimismo, Miguel Escudero será Jefe Político de Navarra, primero, y Presidente de la Diputación Provincial, después, en 1813. De todo ello, se puede sospechar que en la elección de Francisco de Paula Escudero como diputado suplente influia, en alguna manera díficil de determinar, el ascendiente politico de su hermano y la necesidad de mantener algún nexo con la desaparecida Diputación del Reino.

Aunque posteriormente llegaría a ser Ministro de Marina y Guerra durante el Trienio Liberal, el diputado suplente Francisco de Paula Escudero fue una figura absolutamente pasiva en los debates gaditanos, no conociéndosele prácticamente ninguna iniciativa, quizás por ausencia de preparación. Solamente tuvo alguna intervención directa en relación con el tema de las relaciones entre la Regencia y las tropas de Espoz y Mina y fue miembro de las Comisiones de Guerra y Marina $^{39}$. Aunque en su caso cabe admitir la extrañeza en relación con su inocuo proceder dado el importante peso político de su hermano, se ha llamado la atención sobre los caracteres que compartiría dicho diputado suplente navarro con los diputados suplentes de las Provincias Vascongadas: desconexión con el país de origen y desconocimiento de sus singularidades institucionales, carencia de experiencia política y de gestión de asuntos públicos, y falta de vínculos con los demás representantes de los dichos territorios, probada ésta última por la falta de iniciativas coordinadas entre ellos ${ }^{40}$. Todo un mundo de diferencia, por lo que se ve, entre los representantes vasconavarros en Bayona y los que nos encontramos en Cádiz. "Allí auténticos comisionados de las instituciones de los territorios vascos llevaron la opinión oficial sobre la Constitución y los Fueros.

37 Pilar Chávarri Sidera, Las elecciones de Diputados a las Cortes Generales y Extraodinarias (1810-1813), op. cit., pp. 336-338; José Ramón Urquijo Goitia, "Vascos y navarros ante la Constitución: Bayona y Cádiz”, op. cit., p.175.

38 Que sepamos, sus lazos de fraternidad han sido mencionados tan sólo en Á. García-Sanz Marcotegui, Diccionario Biográfico de los Diputados Forales de Navarra (1840-1931), Pamplona, Gobierno de Navarra, 1996, p. 611.

39 Gregorio Monreal Zia, "Los diputados vascos y navarros (El Reino de Navarra y las Provincias Vascongadas en las Cortes y en la Constitución de Cádiz)", op. cit., pp. 367-368; José Ramón Urquijo Goitia, "Vascos y navarros ante la Constitución: Bayona y Cádiz", op. cit., p. 178.

40 Gregorio Monreal Zia, "Los diputados vascos y navarros (El Reino de Navarra y las Provincias Vascongadas en las Cortes y en la Constitución de Cádiz)", op. cit., p. 365. 
Las apelaciones ante las Asambleas parlamentarias españolas al respeto a la ...

Aquí unos residentes originarios de las provincias se convierten en diputados por la voluntad de un puñado de residentes más o menos ocasionales en Cádiz", a lo que se añadiría el hecho real de la actividad concertada de los representantes vascongados y navarros en la capital labortana ${ }^{41}$.

La elección del ineficaz, según revelaría su gestión parlamentaria, Francisco de Paula Escudero sería más inexplicable si cabe si consideramos la relevante presencia en los debates preconstituyentes de Alejandro Dolarea, el que habría sido el autor del documento del documento presentado por la Diputación a la Asamblea de Bayona en 1808, tratando de vender las bondades paraliberales de la constitución histórica de $\mathrm{Navarra}^{42}$, y que a partir de 1809 intentará realizar idéntica labor de marketing en Sevilla y Cádiz. Alejandro Dolarea se trasladó en 1808 a Sevilla al negarse a reconocer a José I como rey, y en septiembre de 1809 fue elegido como miembro de la Junta de Legislación, para preparar la Constitución de Cádiz, así como de la de Ceremonial de Cortes. Por lo tanto, estuvo ciertamente al tanto del clima historicista que se respiraba en los ambientes que dirimían sobre la dirección a tomar por el proceso constituyente que comenzaría en 1810. En consonancia con ese clima, trató de repetir la estrategia desarrollada en Bayona por la Diputación de Navarra, en relación con la defensa de la constitución histórica de Navarra, presentando a ésta en clave paraliberal. Dolarea confeccionó en 1809 un informe para la Junta Central, en el momento de la Consulta al país, en el que, según afirmaba en carta a Jovellanos, había expuesto "con simplicidad la Constitución del Reyno", habiendo tenido, según se recogía en la misma misiva, "la satisfacción de haber merecido ese papel una acogida superior a sus méritos"43. En una solicitud de mayo de 1810 en la que pedía el pago de unos retrasos por los cargos desempeñados y que consta en su expediente personal, el propio Dolarea afirmó que, habiendo llegado a Sevilla en mayo del año anterior, había cumplimentado el encargo que le había hecho el "Ministro de gracia y justicia (al tiempo) Don Benito Hermida de la exposición historial y política de la Constitución de Navarra"44. Lamentablemente, ese informe se perdió, seguramente porque lo extrajo del sitio en el que se encontraba el mismo Hermida, Ministro de Gracia y Justicia, como comentaba Dolarea, en la época de la Junta Central y Consejero de Estado en una de las Regencias del periodo 1810-1814, para utilizarlo en la redacción de su opúsculo Breve noticia de las Cortes, Gobierno, o llámese Constitución del Reyno de Navarra, publicada en Cádiz en 1811, y vuelto a imprimir en Santiago al año siguiente. Con todo, hay que decir que existe en el Archivo del Congreso de los Diputados un extracto de la memoria, redactada por Dolarea en 1809, elaborado por Francisco Redondo para la Junta de Ordenación y Redacción, órgano que analizaba y resumía los informes que iban llegando a la Junta Central de Sevilla ${ }^{45}$. Ese extracto ha sido

41 Ibid.

42 Sobre la figura de Alejandro Dolarea, puede verse Fernando Mikelarena Peña, "Discursos en torno a la Constitución Histórica de Navarra hasta 1813. Origen del concepto y adaptaciones a un contexto cambiante", op. cit., pp. 132-136.

43 Jean Baptiste Busaall, “Constitución histórica y revolución liberal: el reino de Navarra, ¿un modelo posible para la reforma institucional en las Cortes de Cádiz?”, op. cit., p. 80.

44 Archivo Histórico Nacional (AHN), FC-MํJusticia_Mag_Jueces, 4390, Exp. 2280, Expediente personal del Juez Alejandro Dolarea, ff. 13-13v.

45 Jean Baptiste Busaall, “Constitución histórica y revolución liberal: el reino de Navarra, ¿un modelo posible para la reforma institucional en las Cortes de Cádiz?”, op. cit., pp. 80-81. Francisco 
recuperado en una obra publicada hace unos pocos años ${ }^{46}$. Tiene el título de Quaderno Segundo de la memoria de Don Alexandro Dolarea. Se mencionan primeramente las Leyes Fundamentales [de la Constitución navarra], distinguiéndose varios apartados: el referido al poder legislativo, el referido al poder ejecutivo y el referido al poder judicial. Por consiguiente, a pesar del desamparo producido por el vacío institucional y de las dificultades inherentes a que los debates preconstituyentes y constituyentes, tanto los acaecidos en los órganos habilitados al efecto como los difundidos a través de la publicística, se desarrollaron en circunstancias excepcionales y a muchos kilómetros del territorio navarro, y sin que la representación navarra tuviera voces directas relevantes, Dolarea pudo poner sobre la mesa las características del entramado constitucional del que era defensor en función de su puesto de síndico. En un artículo anterior, ya pusimos de manifiesto el carácter temprano de las aportaciones de Dolarea, en comparación con las contribuciones referidas a las constituciones históricas de otras regiones españolas, así como su engañoso éxito al quedar reflejados algunos de sus contenidos en el Discurso Preliminar de presentación de la Constitución de $1812^{47}$.

Teniendo en cuenta su preparación ${ }^{48}$ y su biografia posterior ${ }^{49}$, constituye todo un misterio el por qué Dolarea no fue elegido diputado suplente cuando él

Redondo García, abogado de los Reales Consejos desde 1802, fue nombrado en agosto de 1809 miembro "de la Junta de Ordenación y Redacción de los informes y memorias que se presentaban a la Central". En septiembre de 1809 fue designado Oficial de la Secretaría General del Supremo Consejo de España e Indias. En 1812 fue nombrado fiscal de la Audiencia de Asturias de donde pasó en 1825 a la fiscalía de la Audiencia de Valladolid. Finalmente, acabó siendo Ministro del Tribunal Supremo de España e Indias. Veáse AHN, FC-Mo_Justicia_Mag_Jueces, 4613, Exp. 5.397 .

46 Francisco Redondo, "Extracto de la memoria n ${ }^{\circ} 28$ de don Alejandro Dolarea acerca de la Constitución de Navarra", Junta de Ordenación de Redacción de Cortes de la Suprema Junta Central y Gubernativa del Reino (Archivo Congreso de Diputados, legajo 10, número 30 , 10 folios manuscritos). Reproducido en Jean Baptiste Busaall y Lartaun de Egibar Urrutia, Las instituciones del Reino de Navarra en el debate histórico jurídico de la revolución liberal, op. cit., pp. 175-182.

47 Fernando Mikelarena Peña, "Discursos en torno a la Constitución Histórica de Navarra hasta 1813. Origen del concepto y adaptaciones a un contexto cambiante", op. cit., pp. 155-157.

48 Alejandro Dolarea Pascual de Nieva nació en Pamplona en 1758 y falleció en la misma ciudad en 1829. Hijo y sobrino de abogados del Real Consejo de Navarra, estudió Filosofía en el convento de los Franciscanos en Pamplona y Leyes en Huesca, donde habría sido alumno de Victorián de Villava. Trasladado a Pamplona hacia finales de la primavera de 1778, Dolarea "fue individuo de la Academia Teórico-Práctica" de dicha ciudad, "de la que fue vicepresidente en varias ocasiones", siendo "recibido de abogado del Consejo Real de Navarra el 24 de octubre de 1780". Desde que fue recibido tenía despacho abierto de abogado. En los años siguientes fue Fiscal interino del Consejo de Órdenes de Navarra, Auditor de Guerra, Abogado de Pobres y Reos, Abogado del Clero y representante jurídico de varias localidades navarras. En 1793 fue nombrado regidor en Pamplona. Participó en las Cortes de Pamplona de 1794-1797 y en las de Olite de 1801. Nombrado síndico del Reino en 1793, junto con Manuel Lejalde y Francisco Ibañez, ocupó ese cargo hasta 1808, año éste en que se trasladó a Sevilla al negarse a reconocer a José I como rey. En septiembre de 1809 fue elegido como miembro de la Junta de Legislación, para preparar la Constitución de Cádiz, así como de la de Ceremonial de Cortes. Cfr. Fernando Mikelarena Peña, "Discursos en torno a la Constitución Histórica de Navarra hasta 1813. Origen del concepto y adaptaciones a un contexto cambiante”, op. cit., pp. 133-134 y 148-155.

49 Además de otros cargos para los que fue designado, pero de los que finalmente no pudo tomar posesión, fue nombrado fiscal de la Audiencia de Sevilla en 1812, Alcalde de Casa y Corte en 1814 y Consejero de Órdenes en el mismo año. Llegó a la titularidad de Ministro de dicho 
estaba en Cádiz en aquella época, tal y como se puede comprobar en la circunstancia de que fuera uno de los compromisarios que eligiera a Francisco de Paula Escudero. Siendo, además, que fue elegido diputado a Cortes en la legislatura de 1813, no cabe duda de que habría desempeñado un papel mejor que el del hermano de Miguel Escudero, el miembro de la Diputación a la que asesoró desde 1801 hasta 1808. Tampoco puede pensarse, a tenor de la flojedad de la labor parlamentaria del diputado suplente, que asistamos a una estrategia de división del trabajo mediante la cual uno daba la cara en la cámara y el otro diseñaba estrategias discursivas y relaciones en red, que todo lo más habrian sido llevadas a cabo por Dolarea en exclusividad según se entiende de las memorias que escribió y que inspiró estos años.

Pese a todo, es preciso consignar que nos consta la labor de asesoramiento desarrollada por Dolarea durante esos años a favor de la actividad de las personas que mantenían el hilo de la continuidad de la representación de la desaparecida Diputación. En relación con una reclamación del exsíndico Manuel de Lejalde, que en octubre de 1814 fue nombrado oidor de la audiencia de Galicia, tal y como comunicó por carta a la Diputación de Navarra, carta que fue leída en la sesión de ésta de 24 de octubre de $1814^{50}$, Miguel de Valanza y Carlos Amatria, miembros de la Diputación legítima en el exilio, informaban que, mientras aquél les auxilió en Sevilla durante dos meses, trasladándose después a Portugal y Galicia "bastante antes que se levantase el sitio de Cadiz", en contraposición con su actitud, a Dolarea "cuasi siempre lo tuvimos en Sevilla y en Cádiz dispuesto a promover con nosotros los mismos intereses de V. S. Y. y de los Pueblos y naturales aun después de haber sido nombrado Juez tanto acompañándonos personalmente como por escrito" 51 . Nótese, asimismo, que a tenor de estas últimas informaciones, Valanza y Amatria, los dos miembros de la Diputación legítima en el exilio, también estuvieron en Sevilla y Cádiz junto con Dolarea, no entendiéndose los motivos por los cuales no se postulara su candidatura para ser la voz navarra en el parlamento gaditano.

\section{E1 intento de legitimar el nuevo orden constitucional gaditano con arreglo a los parámetros constitucionales propios.}

Vistos los fracasados intentos de las personas ligadas a la Diputación presentes en Sevilla y Cádiz de tener representación ligada al tejido institucional propio en las Cortes gaditanas y analizadas las limitaciones del diputado suplente finalmente presente en ellas (con lo que se verifica que aquélla trató, adecuándose al contexto, de obviar la problemática de la representación en un foro parlamentario extraño), pasaremos a continuación a profundizar en la

Consejo de Órdenes en 1815. Se le nombró miembro del Consejo de Castilla en 1820, siendo rehabilitado para el mismo en 1823. En 1824 se jubiló y se instaló en Pamplona. Fue elegido Diputado a Cortes por Navarra en las elecciones indirectas celebradas en septiembre de 1813, así como en el Trienio, en la legislatura de 1820-1821, militando entre los liberales moderados. Cfr. Fernando Mikelarena Peña, "Discursos en torno a la Constitución Histórica de Navarra hasta 1813. Origen del concepto y adaptaciones a un contexto cambiante”, op. cit., p. 134.

50 ARGN, Reino, Actas de la Diputación, libro 30, Desde 28 de mayo de 1814 a 20 de diciembre de 1816 , f. 63v.

51 Ibid., f. 308r. 
cuestión de cómo las instituciones navarras ensayaron un intento de legitimación del nuevo orden constitucional con los parámetros constitucionales propios presentando una propuesta de convocatoria de las Cortes navarras para el juramento de la Constitución doceañista. Ese intento de conciliación es particularmente llamativo porque, según veremos, no sólo es que el texto constitucional aboliera de facto el ordenamiento constitucional navarro; además, el liberalismo gaditano ya marginó al legislativo navarro (que hay que reseñarlo, era la única cámara con potestad legislativa tras 1717, aparte de las Cortes de Castilla y de la cámara surgida en Cádiz) de la convocatoria de aprobación y juramento del texto constitucional que previó para otras asambleas y cuerpos, bien que de menor rango, como las juntas generales de Vascongadas. Sea como sea, según veremos, la propuesta navarra fue motivada para evitar que las instituciones navarras quedaran por entero fuera de la ley de manera absoluta y con la finalidad de escapar del rigurosísimo castigo que ello merecía.

\subsection{La abolición de la constitución histórica navarra por parte de la constitución española de 1812.}

Las tesis manejadas por Alejandro Dolarea en los escritos anteriormente mencionados, que perseguían, de forma similar a como aconteció en Bayona en 1808, salvar los muebles como fuera ante los nuevos moldes del constitucionalismo liberal, insistiendo en la misma linea discursiva que remarcaba el carácter paraliberal de la constitución histórica navarra, ante la esperanza de que la misma encontrara cierta receptividad en el foro gaditano, no sólo nutrieron el opúsculo de Benito Hermida. También empaparon el Discurso preliminar leído en las Cortes al presentar la Comisión de Constitución el Proyecto de ella52, en el que hay destacadas referencias apologéticas a la Constitución histórica de Navarra ${ }^{53}$. Ese discurso preliminar fue leído por Agustín de Argüelles, a quien se le ha solido atribuir tradicionalmente su autoría, recientemente asignada a otro diputado ${ }^{54}$, en la sesión de 18 de agosto de $1811^{55}$. Sin embargo, como veremos, esas alabanzas finalmente no sirvieron para nada porque la Constitución de 1812 haría caso omiso del sistema foral navarro.

52 Se puede consultar en Constitución politica de la Monarquía Española, promulgada en Cádiz a 19 de marzo de 1812, Reimpresa en la Imprenta Nacional de Madrid, Año de 1820, pp. 1-120.

53 Fernando Mikelarena Peña, "Discursos en torno a la Constitución Histórica de Navarra hasta 1813. Origen del concepto y adaptaciones a un contexto cambiante", op. cit., pp. 155-157.

54 Coronas González es de la opinión que la autoría del Discurso Preliminar correspondió al diputado por Cataluña José Espiga y Gadea, considerado la cabeza del sector liberal entre los eclesiásticos. Cfr. Santos Manuel Coronas González, "Leyes fundamentales y Constitución de la Monarquía Española de 1812", Iura vasconiae: revista de derecho histórico y autonómico de Vasconia, 8, 2011, pp. 54-55, nota 13.

55 Diario de Sesiones de las Cortes Generales y Extraordinarias, dieron principio el 24 de septiembre de 1810, y terminaron el 20 de septiembre en 1813, Madrid, 1870, 9 volúmenes, Sesión de 18 de agosto de 1811, Número 320, Página 1651. Hemos consultado la versión disponible en Internet en la dirección

http://www.cervantesvirtual.com/servlet/IndiceTomosNumeros?portal=56\&Ref=14075. No obstante, en Constitución política de la Monarquía Española, promulgada en Cádiz a 19 de marzo de 1812, Reimpresa en la Imprenta Nacional de Madrid, Año de 1820, se aclara que se leyó por partes: la primera parte el 17 de agosto (p. 55), la segunda parte el 6 de noviembre (p. 92) y la tercera parte el 24 de diciembre (p. 120). 
Se ha dicho del mencionado Discurso preliminar que constituye "una pieza única desde la perspectiva del aprovechamiento del pasado medieval como instrumento al servicio de la legitimación de la obra constitucional", presentándose la nueva constitución "como una restauración de derechos y referentes jurídicos arraigados en la misma esencia de la nación originaria, que reclama su reactualización. De este modo, se salvaguardaba a la constitución gaditana de cualquier acusación de innovación revolucionaria, insertándola en las exigencias de reposición de una supuesta constitución histórica, cuya invocación se interpreta como consustancial a la propia salvación de la patria" 56 .

En ese discurso se subraya el hilo de continuidad existente entre las constituciones históricas de Aragón, Navarra y Castilla y el proyecto constitucional que entonces se presentaba ${ }^{57}$, así como con las leyes presentes en "la inmensa colección de los cuerpos del derecho, que forman la Jurisprudencia española", habiendo sido "forzoso entresacar con gran cuidado y diligencia las leyes puramente fundamentales y constitutivas de la Monarquía". Esas afirmaciones se acompañan de un relato histórico que sostienen que las antiguas libertades, perdidas primero en Castilla y luego en Aragón a la par de la desaparición de los sistemas constitucionales tradicionales fundados en el pacto entre el rey y el reino a través de las Cortes, solamente se conservaban en Navarra y Vascongadas a pesar de los intentos de los últimos monarcas por menoscabarlas ${ }^{58}$. En ese relato histórico se apunta una cuestión que no resulta baladí, sobre todo en cuanto que la constitución de 1812 hará tabla rasa de los sistemas constitucionales forales. Nos referimos a la recuperación de la legislación visigótica en toda España tras el inicio de la Reconquista, de donde se infiere que los sistemas constitucionales de Castilla, Aragón, Navarra y Vascongadas como sistemas garantizadores de las libertades tradicionales lo hacian en cuanto que serian meras continuidades de los parámetros asentados en la monarquía goda 59 . Con todo, el redactor del discurso asumía que todas las constituciones históricas mencionadas no tenían el mismo grado de capacidad salvaguardora de las libertades tradicionales. Al comparar las constituciones antiguas de Aragón y de Castilla se tiene muy claro que "Aragón fue en todas sus instituciones más libre que Castilla"60.

En el análisis comparativo realizado por dicho Discurso Preliminar se ensalzan las virtudes de la Constitución histórica de Navarra, la única todavía con vida en la época junto con las de las tres provincias vascongadas, mencionándose al final de párrafo también las bondades de las de éstas últimas. Las loas que se dedican al sistema foral navarro entre las páginas 14 y 16 del Discurso son tan exageradas que hacen que el carácter apologético de los informes elaborados por Dolarea y del folleto de Hermida, de los que el documento que ahora estamos comentando se nutre, parezca menor del que es,

56 José Manuel Nieto Soria, Medievo constitucional. Historia y mito político en los orígenes de la España contemporánea (ca. 1750-1814), op. cit., p. 162.

57 Discurso preliminar leido en las Cortes al presentar la Comisión de Constitución el Proyecto de ella, p. 2.

58 Ibid., pp. 17-21.

59 Ibid., pp. 9-10.

60 Ibid., p. 10. 
sobre todo en la medida en que aquél servía de presentación nada menos que al primer texto constitucional propiamente dicho del Estado liberal español ${ }^{61}$.

Para comprobar que ese panegírico párrafo no iría más allá de lo retórico no hacia falta esperar a los debates en torno al articulado del proyecto de los meses inmediatamente posteriores ni a la aprobación del texto final. En otra parte del Discurso preliminar se abordaba la cuestión del gobierno interior de las provincias dejando en el limbo de la indefinición tanto a las Cortes de Navarra como a las juntas provinciales de Alava, Guipúzcoa y Vizcaya y a las diputaciones respectivas dimanadas de cada una de esas cuatro asambleas, las únicas subsistentes, junto con la asturiana, en el Estado tardoabsolutista español, y siendo la navarra la única con potestad legislativa propiamente dicha. Si por un lado se sostenía que en el gobierno de provincias y pueblos se había "mantenido de algún modo el espíritu de nuestra libertad civil, a pesar de las alteraciones que han experimentado las leyes fundamentales de la Monarquía con la introducción de dinastías extrangeras", a continuación se expresaba indisimuladamente la dificultad de los liberales españolas para garantizar su subsistencia. De esta forma, tras apuntar que "no es fácil resolver si el haberse conservado en los pueblos los ayuntamientos baxo formas más o menos populares, y en algunas provincias la reunión periódica de juntas, como sucede en las vascongadas, reyno de Navarra y principado de Asturias \&c., procede de que el Gobierno que proscribió la celebración de Cortes hubiese respetado el resentimiento de la Nación, o bien creído conveniente alucinarla, dexando subsistir un simulacro de libertad que se oponía poco a la usurpación que había hecho de sus derechos politicos", la Comisión encargada de redactar el proyecto de texto constitucional se desentendía del asunto y dejaba "gustosa la resolución de este erudito problema a los que hayan de entrar en adelante en la gloriosa carrera de escribir la historia nacional con la exactitud e imparcialidad de hombres libres", limitándose solo a presentar mejoradas nuestras instituciones municipales para que sirvan de apoyo y salvaguardia a la ley fundamental de la Monarquía"62. Eso

61 Alli se dice textualmente lo siguiente: "La constitución de Navarra como viva y en exercicio no puede menos de llamar grandemente la atención del Congreso. Ella ofrece un testimonio irrefragable contra los que se obstinen en creer extraño lo que se observa hoy en una de las más felices y envidiables provincias del reyno; provincia en donde quando el resto de la Nación no ofrecía más que un teatro uniforme en que se cumplía sin contradicción la voluntad del Gobierno, hallaba éste un mural inexpugnable en que iban a estrellarse sus órdenes y providencias". Una expresión similar en relación con el régimen foral navarro, afirmándose que representaba "una antemural contra los despotismos del govierno", figura en un informe estadistico elaborado hacia octubre de 1810 y remitido por el Conde de Melito a Napoleón y que fue publicado por Idoia Estornés Zubizarreta ("Descripción del País Vasco, Aragón y Cataluña a la luz de un designio napoleónico. El País traspirenaico en 1810", en Homenaje a Julio Caro Baroja, tomo II, 1986, San Sebastián, 699-711). Anteriormente, Polverel, el sindico delegado de la Baja Navarra en París ante la Asamblea Nacional, ya se había significado en el mismo sentido. En un apartado del alegato del Tableau se estudian las analogias y diferencias entre la Constitución del Reino de Navarra y la antigua Constitución de la Monarquía Francesa, desembocando en un elogio de la primera que nos recuerda al que se constata en el Discurso Preliminar. Finalmente, se concluye: "De todas las Constituciones de nuestra Europa moderna, la de Navarra es la menos defectuosa; ha hecho más que ninguna otra por la libertad civil y politica; ha hecho, por la libertad y la igualdad, todo lo que era posible conciliar con la distinción de los Estamentos". Cfr. Fernando Mikelarena Peña, "La Constitución histórica Navarra y el surgimiento del estado liberal. El espejo bajonavarro en 1789”, op. cit.

${ }^{62}$ Discurso preliminar leido en las Cortes al presentar la Comisión de Constitución el Proyecto de ella, pp. 92-93. 
es lo único que se dice de las Cortes de Navarra y de las juntas generales vascongadas, algo más desde luego de lo que se manifiesta de las diputaciones forales vasconavarras de las que no hay ninguna mención en las páginas ${ }^{63}$ que hablan en este Discurso preliminar acerca de las diputaciones provinciales.

$Y$ es que, en realidad, la mención de las constituciones históricas de los diferentes reinos españoles en ese discurso preliminar no fue más que un truco retórico para anclar históricamente el proyecto que se presentaba, dotándolo de la legitimidad que podía dar la reconstrucción de un hilo de continuidad entre las antiguas instituciones y las nuevas que se configuraban ahora. Los constituyentes gaditanos, en rigor, no estaban dispuestos a sacrificar su solución homogeneizadora mediante el reconocimiento de legitimidades jurídicoinstitucionales territoriales que pudieran ir en contra de los intereses que iban a defender ${ }^{64}$.

De cara al futuro, la evidencia del carácter retórico de la apología del régimen navarro que se hacía en el discurso preliminar del proyecto de constitución pudo constituir un factor para el aumento de las frustraciones, vista la supresión de la misma que finalmente hacia el texto constitucional definitivo. En cuanto a esto último, hay que recordar que Ángel Sagaseta de Ilúzdoz en su folleto de 1839/1840 Fueros fundamentales del reino de Navarra y defensa legal de los mismos no dejó de citar dicho discurso preliminar al mencionar que "La constitución de Navarra, como viva y en ejercicio, no puede menos de llamar la atención pública" por ofrecer un testimonio irrefragable contra los que se obstinan en creer estraño de España el gobierno representativo" ya que "en Navarra cuando los demás reinos de la Península no ofrecían más que un teatro uniforme, en que se cumplía sin contradicción la voluntad del gobierno, hallaba éste un antemural inexpugnable, en que iban a estrellarse sus órdenes y providencias, siempre que eran contra la Ley o procomunal del Reino"65. A la inversa, tampoco debe caer en el olvido que esos mismos párrafos del discurso preliminar, independientemente de lo inauténticos que fuesen, también extendian un manto de sospecha sobre la constitución histórica de Navarra en los sectores más uniformistas del realismo, que también los habia y que pronto comenzarian con sus ataques al régimen navarro, continuando los de la época de Godoy que, a su vez, proseguían la línea emprendida inicialmente por Campomanes ${ }^{66}$.

La Constitución gaditana, promulgada el 19 de marzo de 1812, no incorporó, a diferencia del proyecto de texto constitucional presentado el verano anterior por la Comisión de Constitución, ninguna exposición de motivos ni ninguna digresión

\footnotetext{
63 Ibid., pp. 100-103.

64 Jean Baptiste Busaall, “Constitución histórica y revolución liberal: el reino de Navarra, ¿un modelo posible para la reforma institucional en las Cortes de Cádiz?”, op. cit., p. 96.

65 Ángel Sagaseta de Ilúzdoz, Fueros fundamentales del reino de navarra y defensa legal de los mismos, Pamplona, 1840, p. 13.
}

66 Sobre tales ataques por parte del gobierno central, cfr. Rodrigo Rodriguez Garraza, Navarra de reino a provincia (1828-1841), op. cit., pp. 33-141; María Cruz Mina Apat, Fueros y revolución liberal en Navarra, op. cit., pp. 60-173. Asimismo, sobre el más poderoso ataque intelectuar a las bases de sistema constitucional navarra por parte del absolutismo centralista, cfr. Fernando Mikelarena, "La refutación absolutista del discurso pactista navarro. José María de Zuaznávar y Francia y el Ensayo Histórico-Crítico sobre la legislación de Navarra", Cuadernos de historia del derecho, 18, 2011, pp. 241-267. 
de signo historicista67. Y ello debido a que "la nación y la unidad constitucional era el principio general" del enfoque adoptado. Se abandonaba en la cuestión territorial cualquier perspectiva historicista, según la cual la nación española debía contemplarse como "esencialmente plural", y se partía de la consideración unitarista de interpretarla como surgida "de un pacto de voluntad general, en cuyo caso no era una reunión de territorios sino de voluntades"68.

Que los equívocos tendian a disiparse lo demostraba asimismo el hecho de que en el texto constitucional final no se dijera nada sobre los fueros vasconavarros, resultando ignorados o no mencionados ${ }^{69}$. Tampoco se registró en ningún momento del periodo que va de las reuniones de las Cortes de septiembre de 1810 a marzo de 1812 ningún debate propiamente dicho acerca de los $\operatorname{mismos}^{70}$.

De cualquier forma, considerando el desenlace final, un anticipo del mismo, así como una explicación de la aparente contradicción entre lo enunciado en dicho Discurso preliminar y aquél, la encontramos en el debate en torno a los artículos 10 y 11 , relativos a las entidades territoriales que componian la monarquía, que tuvieron lugar en la sesión del 2 de septiembre de 1811. El artículo 11 citaba, en referencia a los territorios que comprendía el territorio español en la Península e islas adyacentes a "Aragón, Asturias, Castilla la Vieja, Castilla la Nueva, Cataluña, Córdoba, Extremadura, Galicia, Granada, Jaén, León, Murcia, Navarra, Provincias Vascongadas, Sevilla y Valencia, las islas Baleares y las Canarias". Como se ve, se menciona Navarra, pero sin la intitulación de Reino, aún cuando todavía lo era. El artículo 12 decía que "se hará una división más conveniente del territorio español por una ley constitucional, luego que las circunstancias políticas de la Nación lo permitan". En relación con el segundo de esos dos artículos, el diputado Borrull, que planteaba un discurso similar al de Dolarea si bien referido al País Valenciano ${ }^{71}$, abogaba por mantener el nombre y el territorio de los antiguos reinos para las nuevas demarcaciones porque sería perjudicial cambiar aquéllos y que se agregaran "los pueblos de los unos a los otros" ya que ello impediría "la íntima unión que media entre los pueblos de un mismo reino". Pues bien, esa intervención fue replicada por Muñoz Torrero desde una perspectiva jacobina que

67 Bartolomé Clavero Salvador, "Entre Cádiz y Bergara: lugar de encuentro de la Constitución con los Fueros”, Anuario de Historia del Derecho Español, 59, 1989, p. 224.

68 Santos Manuel Coronas González, "Leyes fundamentales y Constitución de la Monarquía Española de 1812", op. cit., p. 57. Sobre el debate entre el concepto individualista de nación y de representación nacional, defendido por los liberales, y los conceptos organicista y corporativo (estamental o territorial, o ambas cosas simultáneamente) de los diputados realistas y americanos, puede verse Joaquín Varela Suanzes-Carpegna, "Nación, representación y articulación territorial del Estado en las Cortes de Cádiz”, Revista de Historia Jerónimo Zurita, 87, 2012, pp. $11-40$.

69 Jean Baptiste Busaall, “Constitución histórica y revolución liberal: el reino de Navarra, ¿un modelo posible para la reforma institucional en las Cortes de Cádiz?”, op. cit., p. 96.

70 Gregorio Monreal Zia, "Los diputados vascos y navarros (El Reino de Navarra y las Provincias Vascongadas en las Cortes y en la Constitución de Cádiz)”, op. cit., p. 380.

71 Carmen García Monerris, "Lectores de historia y hacedores de politica en tiempos de fractura $<<$ constitucional>>", Historia Constitucional. Revista Electrónica de Historia Constitucional, 3, 2002; Fernando Mikelarena Peña, "Discursos en torno a la Constitución Histórica de Navarra hasta 1813. Origen del concepto y adaptaciones a un contexto cambiante", op. cit., pp. 146-147. 
nos retrotrae a los comentarios suscitados en la Asamblea Nacional francesa el 12 de octubre de 1789 por la petición bajonavarra de conservación del título de rey de Navarra en las personas de los reyes franceses ${ }^{72}$, y en la que se venía a ofrecer una interpretación de la prédica del discurso preliminar de la constitución al entender ésta como un precipitado de las virtudes de las leyes aragonesas y navarras que se extendian a los demás reinos en un proceso de igualación que no conllevaba rebaja alguna para ningún territorio. Sus palabras textuales fueron: "Estamos hablando como si la nación española no fuera una, sino que tuviera reinos y estados diferentes. Es menester que nos hagamos cargo que todas estas divisiones de provincias deben desaparecer, y que en las Constitución actual deben refundirse todas las leyes fundamentales de las demás provincias de la Monarquia, especialmente cuando en ella ninguna pierde. La comisión se ha propuesto igualarlas todas; pero para esto, lejos de rebajar los fueros, por ejemplo, de los navarros y aragoneses, ha elevado a ellos a los andaluces, castellanos, etc., igualándolos de esta manera a todos para que juntos formen una sola familia con las mismas leyes y Gobierno. Si aquí viniera un extranjero que no nos conociera, diría que había seis o siete naciones. La comisión no ha propuesto que se altere la división de España, sino que deja facultad a las Cortes venideras para que lo hagan, si lo juzgaran conveniente, para la administración de justicia, etc. Yo quiero que nos acordemos que formamos una sola Nación, y no un agregado de varias naciones"73.

En el resto del proceso de discusión del proyecto de texto constitucional elaborado por la Comisión encargada de ello, iniciado el 25 de agosto de 1811, apenas salió a relucir la constitución histórica de Navarra. Solamente cabe mencionar las alusiones que efectuó Ramón Giraldo, diputado por La Mancha que llegó a ser durante un mes presidente de las Cortes y que había sido fiscal del Consejo de Navarra hasta agosto de 1808, distinguiéndose por una actitud de resistencia frente a los franceses 74 , a varios aspectos ligados a la estructura jurídicoinstitucional navarra como la asunción de la soberanía por parte de los navarros y el reconocimiento de la misma por parte de los reyes, la protección de los derechos de los ciudadanos navarros en cuestiones penales y carcelarias o la

72 Fernando Mikelarena Peña, "La Constitución Histórica navarra y el surgimiento del estado liberal. El espejo bajonavarro en 1789”, op. cit.

73 Diario de Sesiones de las Cortes Generales y Extraordinarias, dieron principio el 24 de septiembre de 1810, y terminaron el 20 de septiembre en 1813, Madrid, 1870, 9 volúmenes, Sesión de 2 de septiembre de 1811, Número 335, pp. 1742-1745, en especial ésta última.

74 El 8 de agosto de 1808 Ramón Giraldo, fiscal del Consejo Real de Navarra, exponía a la Cámara de Castilla en una carta la actuación de dicha institución frente a los franceses y solicitaba instrucciones sobre el traslado de la misma fuera de Pamplona. Afirmaba que desde febrero "no se ha reconocido ni proclamado otra autoridad, ni dominación, que la de nuestros legitimos y verdaderos soberanos y han quedado sin efecto alguno quantas órdenes se han comunicado en contrario sobre el particular al Consejo de Navarra, no dándoles la sobrecarta que se requiere para su cumplimiento según la legislación de este reino" (Rafael D. Garcia Pérez, "El Consejo Real de Navarra, entre el derecho del rey y las libertades del reino (1800-1836)", Anuario de Historia del Derecho Español, 72, 2002, p. 130). La carta se encuentra en AHN, Estado, legajo 6397 (1). En su respuesta de 29 de agosto la Cámara de Castilla no se pronunció y le dio a Giraldo libertad para elegir. De esta forma, la mayor parte de los ministros y subalternos del Consejo abandonarían Pamplona en septiembre y octubre lo que motivó la suspensión del mismo en mayo de 1809 y su sustitución por otro nombrado por los franceses (Ibid., p. 130). 
labor vigilante de la diputación ${ }^{75}$. Asimismo, hay que reseñar la circunstancia que el mismo Argüelles defendió el articulo 173 sobre el juramento real como extraído del régimen politicoinstitucional navarro ${ }^{76}$.

De todas esas alusiones registradas en el proceso de debate del proyecto constitucional, la más relevante es la primera de las mencionadas. Tuvo lugar en torno al artículo tercero del proyecto, que señalaba que "la soberanía reside esencialmente en la Nación, y por lo mismo le pertenece exclusivamente el derecho de establecer sus leyes fundamentales, y de adoptar la forma de gobierno que más le convenga"77. En relación con ello, Giraldo recordó que el 1795 Fernando VII juró mantener los fueros de Navarra ante las Cortes navarras de aquel año, interpretándolo en el sentido de que dicho monarca habia "jurado y reconocido la soberanía en la Nación con la mayor solemnidad, haciendo en esto lo mismo que sus predecesores". Para Giraldo ésa era la causa de que los navarros no hubieran reconocido al gobierno intruso ni a la Constitución de Bayona $^{78}$. El diputado por la Mancha también recordó que no se encontraba en la Constitución de Navarra "la palabra Soberano, sino la de Rey; jamás se dicen vasallos, sino súbditos; y por último, los Reyes ofrecian mantener, observar, guardar las leyes, fueros, usos y costumbres, con lo que reconocían su soberanía de quien hacia estas leyes, y confesaban el poder ejecutivo que les correspondia"79. Giraldo llegaba a ejemplificar la asunción de la soberanía por parte de los navarros mediante una relectura de la unión con Castilla de 15121515. Según él, "Han sido los navarros tan exactos y celosos de sus fueros, que cuando el Rey Católico trató de unir a Castilla aquel reino, no permitieron que fuese por derecho de conquista, sino que ellos mismos usaron de la soberanía, declarando que había cesado de reinar el desgraciado Don Juan de Labrit, y eligieron por Rey a Fernando el Católico con las mismas pautas y condiciones que se han referido; así lo aceptó Fernando y lo sancionaron las Cortes de Burgos de 1515; siendo muy particular que Navarra haya conservado su Constitución integramente en el tiempo que en Castilla se estudiaba para hacerla olvidar, y someterla al despotismo y arbitrariedad. Todos los Reyes en España, desde dicha época, han reconocido la soberanía de la Nación en el único Congreso nacional que había legitimo en la Península, que eran las Cortes de Navarra"80.

Tampoco en el debate constitucional hubo muchas menciones explicitas y directas a los fueros de las Vascongadas, constatándose la contradicción en las diversas alusiones registradas a ellos de que "si bien el principio que presidia el liberalismo era el de igualación, y por lo tanto propendía a su desaparición, los discursos trataban de glorificarlos como un elemento de libertad" y "las citas de

75 Jean Baptiste Busaall, “Constitución histórica y revolución liberal: el reino de Navarra, ¿un modelo posible para la reforma institucional en las Cortes de Cádiz?”, op. cit., pp. 89-94.

76 Ibid., pp. 95-96.

77 Diario de Sesiones de las Cortes Generales y Extraordinarias ..., Sesión de 28 de agosto de 1811, Número 330, Página 1707.

78 Diario de Sesiones de las Cortes Generales y Extraordinarias ..., Sesión de 29 de agosto de 1811, Número 331, Página 1718.

79 Diario de Sesiones de las Cortes Generales y Extraordinarias ..., Sesión de 29 de agosto de 1811, Número 331, Página 1719.

80Ibidem. 
los mismos les resultaban útiles a los liberales para alejar las críticas de que se importaba un modelo político [el francés], frente a lo que aducían que era todo lo contrario pues proponían una vuelta a los origenes" 81 .

\subsection{La propuesta de agosto de 1813 de convocatoria de Cortes navarras para aprobar y jurar la constitución de 1812 .}

E1 Decreto CXXXIX de 18 de marzo de 1812 sobre "Solemnidades con que debe publicarse y jurarse la Constitución politica en todos los pueblos de la Monarquía, y en los exércitos y armada" dispuso que la Constitución debía de ser publicada solemnemente en cada pueblo, y que, además, debían jurarla "los Tribunales de qualquiera clase, Justicias, Virreyes, Capitanes generales, Gobernadores, Juntas provinciales, Ayuntamientos, M. RR. Arzobispos, RR. Obispos, Prelados, Cabildos eclesiásticos, Universidades, Comunidades religiosas, y todas las demás corporaciones". Al ser citadas las juntas provinciales en esa disposición entre las autoridades y organismos que debian de prestar juramento a la Constitución, se ha remarcado que en virtud de dicho decreto fueron convocadas las Juntas Generales de Alava, Vizcaya y Guipúzcoa para tratar de conciliar el nuevo orden $\mathrm{y}$ el orden foral de esos territorios ${ }^{82}$, no siendo mencionadas las Cortes de Navarra, que, por lo tanto, fueron excluídas del proceso.

En razón de ese Decreto, las Juntas Generales de cada una de las Provincias Vascongadas se reunieron en diferentes momentos del tiempo para realizar el juramento del texto constitucional, no sin problemas como veremos. Dichos problemas fueron anticipados por el cuestionamiento del único representante por Vizcaya en las Cortes de Cádiz, Francisco de Eguía, la antevíspera de la promulgación de la Constitución a la jura a la que se le requirió al igual que a los demás diputados. E1 17 de marzo de 1812 se leyó un oficio de Eguía en relación con una orden del día 15 para que "asistiese sin excusa alguna los días 18 y 19 próximos, a firmar y jurar la Constitución". En él decía "que nunca creyó que esto pudiese entenderse con él, por no haber asistido a sus discusiones, y no haber visto en las corporaciones de que ha sido miembro que hubiese firmado sobre asunto alguno el que no hubiese asistido; y que además, careciendo de instrucciones de su provincia, debia dirigirse por la opinión general de sus paisanos que aman mucho sus fueros; según lo cual no le era permitido obrar contra su voluntad, ni concurrir en calidad de tal Diputado al menor acto que pueda poner en cuestión cual fuese ello". Los diputados debatieron sobre qué hacer con los diputados que no quisiesen firmar y jurar la Constitución y el diputado García Herreros planteó que al individuo que se negara a firmar y jurar la Constitución "sea tenido por indigno del nombre español, privado de todos los honores, distinciones, prerrogativas, empleos y sueldos, y expelido de los dominios de España en el término de veinticuatro horas". Esa propuesta fue aprobada junto con la adición propuesta por el diputado Ortiz de que quedaba "a

81José Ramón Urquijo Goitia, "Vascos y navarros ante la Constitución: Bayona y Cádiz”, op. cit., p. 182 .

82 Bartolomé Clavero Salvador, "Entre Cádiz y Bergara: lugar de encuentro de la Constitución con los Fueros", op. cit., pp. 205-282. 
disposición del Gobierno la ejecución de este acuerdo con todas las precauciones competentes"83.

Otra versión de lo ocurrido nos proporciona algunos datos adicionales. Según se narra, en la sesión secreta de aquel día 17 de marzo de 1812 "el Sr. Eguía expuso que no podía firmar la Constitución por no haber asistido a las sesiones en que se había discutido, y porque su voto era que se conserven sus fueros a la provincia de Vizcaya cuyo Diputado es". La exposición de Eguía, así como la de otro diputado, un tal Llamas, por Murcia, que dijo que no podia jurar la Constitución por no estar de acuerdo con "la soberanía esencial de la nación", "promovieron una larga y triste discusión". En el debate se planteó declarar indignos a esos dos diputados, desposeerlos de honores, grados, empleos y rentas, y expatriarlos o confinarlos. Con todo, no hubo que aplicar contra ellos ninguna medida de castigo porque los dos diputados, sabedores de a qué se arriesgaban en el plano personal, finalmente se aprestaron a firmar y jurar las Constitución ${ }^{84}$.

Esas actas relativas a esa sesión secreta son de gran relevancia porque nos informan de la utilización que los absolutistas comenzaban a hacer de las constituciones históricas de los territorios forales como elemento de confrontación con el liberalismo en Navarra y Vascongadas. En este punto es preciso recordar que el mismo general Eguía sería quien cerrase las Cortes el 4 de mayo de 1814 y detuviera a los dos regentes presentes en ellas y a los diputados liberales más importantes.

Por otra parte, la reunión para la jura de la Constitución por parte de las Juntas Generales vizcainas tuvo lugar en octubre de 1812, la de las Juntas alavesas en noviembre de 1812 y la de las Juntas guipuzcoanas en julio de 1813, en este último caso mucho más tarde a causa de la presencia mucho más dilatada en el tiempo de los franceses en Guipúzcoa.

La reunión más conflictiva fue la vizcaína. En principio, las Juntas Generales de Vizcaya en esa reunión de 18 de octubre de 1812 resolvieron pedir explicaciones a las Cortes o a la Regencia, dado que "poseyendo este Señorio desde tiempo inmemorial la Constitución privativa de este suelo y debiéndola la felicidad todas las generaciones que han gozado de ella", desconocían "si recibida la Constitución política de la Monarquía española es necesario renunciar absolutamente a la Vizcaina, o si son conciliables en todo o en parte las ventajas de las dos". Ese acuerdo fue consecuencia de un encontronazo entre posturas bien disimiles. Mientras algún liberal exacerbado como Ildefonso de Sancho defendió sin matices la jura del texto constitucional, considerando inadmisible su cuestionamiento en el más mínimo aspecto, otros apoderados se manifestaron a favor del mantenimiento del sistema foral. Así Antonio Leonardo de Letona afirmó que antes de "abandonar los fueros del Señorío era menester pensar bien la cosa" y Miguel de Antuñano habló del derecho de Vizcaya a mantener sus fueros, enardeciendo a los asistentes, dando lugar a una lluvia de insultos sobre la

83 Actas de las sesiones secretas de las Cortes Generales Extraordinarias de la Nación española que se instalaron el dia 24 de septiembre de 1810 y cerraron sus sesiones el 14 de igual mes de 1813, de las celebradas por la diputación permanente de Cortes y de las secretas de las Cortes Ordinarias, Madrid, Imprenta de J. A. García, 1874, p. 597.

84 Joaquín Lorenzo Villanueva, Mi viaje a las Cortes. Obra inédita, op. cit., pp. 337-338. La información sobre el origen geográfico de Llamas en la página 362. 
Las apelaciones ante las Asambleas parlamentarias españolas al respeto a la ...

minoría constitucionalista y provocando un cambio de dirección en un ambiente tenso en el pensamiento de la asamblea en el sentido del acuerdo finalmente tomado. El general Renovales, testigo de los hechos, acusaría a Mendizábal, general en jefe del séptimo ejército a quien la Regencia había encargado del asunto, de contemporeizar excesivamente con quienes se negaban a jurar la constitución 85 .

Cuando, un mes más tarde, llegó la noticia de lo sucedido en Guernica, la reacción de los constituyentes gaditanos, reacción que ponía sobre aviso a las otras dos juntas provinciales vascongadas sobre la postura a mantener a su vez en el momento de acometer dicho juramento, fue ciertamente furibunda. En la sesión secreta del 16 de noviembre se encargó al general Mendizábal "que a fin de reprimir dichos desórdenes, comunicase por extraordinario las órdenes más enérgicas al jefe de la provincia, para que, usando de cuantos medios estuviesen en su arbitrio, cortase dicho mal en su principio, e hiciese inmediatamente publicar y jurar la Constitución, sin dilación, restricción, ni modificación alguna". Además, las Cortes resolvieron que se pasara el tema "a la comisión de Constitución, a la que se agregaron los señores Diputados de las Provincias Vascongadas" 86 .

La otra versión de que disponemos de esa sesión secreta habla en parecidos términos. En ella se dice que "se dio cuenta de un oficio de la Regencia en que, refiriéndose a otro que había recibido del general Mendizábal, avisó la desagradable ocurrencia de Vizcaya, en cuya provincia se suspendió la jura de la Constitución por haberse opuesto a ello algunos naturales reclamando la conservación de sus fueros; y aunque otros se esforzaron en que se llevase a efecto lo decretado acerca de esto por las Cortes y la Regencia; así estos esfuerzos como los del general Mendizábal habian sido inútiles. Indicó la Regencia las medidas rápidas y eficaces que había adoptado para cortar este escándalo en su raíz (...). Pareció que antes de resolver sobre este negocio se oiga a la Comisión de Constitución, a la cual pasen todos los documentos, y que se agreguen a ello los Diputados de Vizcaya, Alava y Guipúzcoa. El Sr. Zumalacárregui ${ }^{87}$ hizo presente que hace tiempo que no asiste a las sesiones el Diputado de Vizcaya, y que convendrá se le pase oficio para que concurra a las comisiones; así se acordó" 88 .

85 José Ramón Urquijo Goitia, "Vascos y navarros ante la Constitución: Bayona y Cádiz", op. cit., pp. $184-185$.

86 Actas de las sesiones secretas de las Cortes Generales Extraordinarias de la Nación española que se instalaron el dia 24 de septiembre de 1810 y cerraron sus sesiones el 14 de igual mes de 1813, de las celebradas por la diputación permanente de Cortes y de las secretas de las Cortes Ordinarias, op. cit., p. 753.

87 Se trata de Miguel Antonio de Zumalacárregui e Imaz (1763-1867), hermano del general carlista y distinguido liberal guipuzcoano que ocupó altos cargos en la administración del Estado. Recibido de abogado en la Real Audiencia de Sevilla en 1797, fue destinado en 1803 a la Audiencia de Asturias. En 1808 se posicionó contra los franceses, trasladándose en 1810 a Cádiz. Fue elegido Diputado suplente por Guipúzcoa para las Cortes extraordinarias gaditanas e intervino en diversas comisiones. También fue elegido como diputado en la legislatura ordinaria de 1813. Tras la reacción fernandina, sería castigado con la inhabilitacióm. Durante el Trienio Liberal llegaría a ser magistrado del Tribunal Supremo. En ese momento se deslizó hacia el liberalismo moderado. No obstante, sería represaliado de nuevo tras 1823 , siendo impurificado y rebajado su sueldo. Tras 1833 ocuparía ya cuerpos importantes en la carrera judicial, llegando a ser Ministro de Gracia y Justicia en 1842.

88 Joaquín Lorenzo Villanueva, Mi viaje a las Cortes. Obra inédita, op. cit., p. 473. 
No obstante, mirado el Diario de Sesiones hasta final del año 1812 no aparece ninguna resolución de la Comisión de Constitución.

En Guipúzcoa las Juntas Generales convocadas a finales de julio por el general Castaños juraron la Constitución el 31 de Julio de 1813 señalando que "leída la Constitución, se enteraron de su contenido los Procuradores, quienes conociendo desde luego que según las bases fundamentales de este Código nacional y la Constitución nativa y original de Guipúzcoa tienen una íntima analogía y se conforman esencialmente (...); en esta inteligencia la Junta General admite y jura la Constitución de la Monarquía española". Con todo, el juramento guipuzcoano encierra algunas peculiaridades. En primer lugar, porque en la misma acta de juramento se añadió que se dejaba "encargada a la Diputación para entender con el Gobierno sobre las variaciones [de la Constitución] que la situación y esterilidad de este País fronterizo hacen necesarias para su existencia y bien de la Monarquía", subrayando que "aún para la parte reglamentaria de esta portentosa obra de la Nación, presenta el Código peculiar de la Provincia un modelo digno de que sea seguido, del mismo modo que en lo respectivo a las leyes fundamentales"89. En segundo lugar, porque la Diputación Foral creada tras aquellas mismas Juntas Generales el día de su disolución y sustitución por la Diputación Provincial, el 22 de septiembre de 1813, elaboró en sesión extraordinaria un acta secreta reservada firmada por el jefe politico y presidente de la misma, el conde de Villafuertes, nombrado el 5 de agosto por la Regencia, y los demás miembros de la misma. En ella hay una referencia a las órdenes de la Regencia de 20 de agosto y de 9 de septiembre en las que se decía <<que por las contestaciones de la Provincia (...) no se advierte con la claridad y precisión necesarias, haberse jurado la Constitución de la Monarquia, ni hablado de nombramiento de Diputación provincial arreglada al nuevo sistema >>. También constaba una respuesta de Villafuertes de 16 de agosto que por "su ambigüedad, partiendo de la aceptación condicionada de la Constitución, había sin duda sorprendido e irritado al Poder central" y la orden, a su vez, de la Regencia de "que el Ejército prestase su apoyo para el inmediato establecimiento del sistema constitucional en todas sus partes, sin retraso ni demora". En el acta reservada la Diputación foral afirmaba que <<viendo que ha llegado el doloroso extremo de que la Regencia intente valerse del estamento de las armas contra los pueblos y habitantes de la Provincia por su constancia en los medios de que se observen sus nativos fueros $>>$, <<convencida en fin de haber llegado el apurado caso de que, según los deseos e instrucciones verbales de la Junta general, celebrada por esta Provincia en la villa de Deva por el mes de Julio último, se ha de hacer una protesta solemne contra semejante inaudita y extraña violencia, acordó conste para perpetua memoria en esta acta reservada, que no consiente ni consentirá jamás esta Provincia de Guipuzcoa en la oposición a sus fueros, privilegios, prerrogativas, libertades, buenos usos y costumbres con que siendo de libre dominio, se entregó voluntariamente a la Real Corona de Castilla el año de 1200, bajo expresa condición de que se guarden y observen inviolablemente $>>90$.

89 María Rosa Ayerbe Irízar, "El gobierno de Gipuzkoa: entre la tradición y el cambio (18081814)", Iura Vasconiae, 8, 2011 , p. 437.

90 Maria Rosa Ayerbe Irízar, "El gobierno de Gipuzkoa: entre la tradición y el cambio (18081814)", op. cit., pp. 438-440; Arturo Cajal Valero, "Paz y Fueros". El conde de Villafuertes. Guipúzcoa entre la "Constitución de Cádiz" y el Convenio de Vergara (1813-1839), Madrid, Biblioteca Nueva, 2002, pp. 57-58. 
Una cuestión relacionada con la postura que se acaba de comentar de las Juntas Generales de las Vascongadas que no ha sido tratada por la historiografia es la de que, al fin y a la postre, dicha postura posee una similitud de fondo con la postura mixtificadora sostenida por Dolarea en los textos que elaboró para Bayona en junio de 1808 y para Cádiz en 1809. Tal y como ha subrayado Rubio Pobes"1, las Juntas Generales de Vizcaya y Guipuzcoa destacaron la "esencial analogía entre los textos de la Constitución gaditana y los fueros vascos", entendidos éstos como códigos liberales, planteándose incluso en el caso guipuzcoano como modelo a aplicar en el resto del Estado. ¿No era eso en resumidas cuentas el propósito de Dolarea, concebido y elaborado unos años antes? ¿No se proponía plantear la constitución navarra como una constitución en la que regía el principio liberal de separación de poderes y que pudiera ser interpretada de forma analógica como compatible con los principios nuevos del liberalismo, sin tener en cuenta las finalidades propias del liberalismo en la esfera de lo socioeconómico y de lo políticojurídico? ${ }^{92}$.

Por lo que respecta a Navarra, ya comentamos más arriba que el Decreto CXXXIX de 18 de marzo de 1812 excluia, por no citarlo, al legislativo navarro de la relación de cuerpos que debían acometer al juramento de la Constitución. Además de ello, los doceañistas también rechazaron una propuesta formulada desde personalidades y/o instituciones navarras para que los Tres Estados navarros fueran convocados a tal efecto. La información al respecto de las actas oficiales de las sesiones secretas de aquéllas son extremadamente escuetas en torno a la cuestión ya que solamente señalan que el 20 de agosto de 1813, es decir, al mes siguiente de haberse reunido la última de las Juntas Generales de Vascongadas, la guipuzcoana (y con los franceses todavía en parte del territorio

91 Coro Rubio Pobes, Revolución y tradición. El País Vasco ante la revolución liberal y la construcción del Estado Español, 1808-1868, Madrid, Siglo XXI, 1996, p. 135-137.

92 En el Quaderno Segundo de la memoria de Don Alexandro Dolarea. Se mencionan primeramente las Leyes Fundamentales [de la Constitución navarra], distinguiéndose varios apartados: el referido al poder legislativo, el referido al poder ejecutivo y el referido al poder judicial figura un exordio por el que Dolarea se habria aplicado a plantear las potencialidades del orden constitucional navarro para el conjunto de España. A su juicio, "para formar la España la que necesita, si no quiere ser en adelante juguete de sus rivales y enemigos, no es necesario mendigar leyes extranjeras, las tiene dentro de su suelo: tiene la ya espresada Constitución de Navarra, que con poca diferencia es la misma que gobernó la Corona de Aragón, y aun toda la España antes de la irrupción de los Árabes". Y seguidamente planteaba los ejes fundamentales de esa constitución española basada en la constitución navarra, formulándolos en catorce puntos que no conllevaban una ruptura con el régimen absolutista, sino solamente una leve reforma del mismo sustanciada en la creación de una diputación permanente que controlara la acción del poder regio, la instauración de un poder judicial independiente que dirimiera los litigios entre el monarca y aquella diputación permanente y el surgimiento de un parlamento cuya periodicidad de reunión no se definía con precisión y que asumía la potestad legislativa junto con el rey. De cualquier forma, en la posibilidad de exportación de la constitución navarra al conjunto del Estado no se hacía ninguna mención a aspectos nucleares del sistema parlamentario liberal, por moderado que éste fuera, tales como la forma de elección de representantes para la cámara parlamentaria. Además, no había ninguna alusión a la mayoría del entramado de medidas de índole socioeconómica, inclusive algunas que estaban en el nervio de las relaciones entre Navarra y el Estado como la unidad de mercado, inherentes al liberalismo, radicando la única excepción en la igualdad contributiva propugnada por el punto decimocuarto. Como se verá más adelante, esos contenidos eran concordantes con la línea del absolutismo moderado y podian ser tenidos en cuenta por liberales del sector jovellanista, pero distaban mucho de los liberales más avanzados que serian los que darian su sello final al texto constitucional en elaboración. 
navarro), para tratar el tema de la Constitución de la monarquía española de 1812, "habiéndose leído una Representación del Sr. Diputado D. Francisco de Paula Escudero, y otra de los individuos de la Diputación de Navarra, D. Miguel Escudero y D. Manuel Díaz del Río, dirigidas a exponer la solicitud de éstos últimos, de que se manden juntar las Cortes generales de aquel Reino, completándose entretanto su Diputación, se resolvió no haber lugar a deliberar"93. Es decir, el acta de dicha reunión nos informa que se presentaron a los diputados españoles dos representaciones, una del único representante de Navarra que tomó parte en las Cortes de Cádiz en calidad de diputado suplente, Francisco de Paula Escudero, y otra de dos miembros de la Diputación de Navarra de entonces que ya habian formado parte de la Diputación de 1808 que había abandonado Pamplona en agosto de aquel año, Miguel Escudero (hermano, por otra parte, del anterior) y Manuel Díaz del Río, en el sentido de que se permitiera la reunión del legislativo navarro, sin precisar siquiera la finalidad que se perseguía.

Sin embargo, las actas no oficiales redactadas por Joaquín Lorenzo Villanueva, testigo de los hechos, nos aportan algunas informaciones complementarias ${ }^{94}$. Según él, "el Sr. Diputado de Navarra, Escudero, presentó un memorial de cuatro Diputados de las antiguas Cortes de aquel reino, en que piden licencia para congregar las Cortes antiguas de él; expuso el Sr. Escudero que esto lo pedian con el objeto de publicar las Constitución al modo que las provincias Vascongadas habian celebrado su junta ordinaria con el mismo objeto. El Sr. Mejia, Zumalacárregui y otros hicieron presente que las Cortes de Navarra eran legislativas, y no las juntas de Vizcaya que sólo eran protectoras de sus fueros, y asi había una notable diferencia entre unas y otras; que por lo mismo no debía permitirse la instalación de las Cortes de Navarra, pues esto sería hacer compatibles dos Cuerpos legislativos en un mismo Estado. A propuesta del Sr. Torrero se acordó no haber lugar a votar sobre este memorial”95.

El contenido de la petición no está claro ni tampoco se puede conocer puesto que no hemos podido localizar la exposición ni en el Archivo General de Navarra ni en el Archivo del Congreso. No obstante, la solicitud no era extemporánea ni extraña en cuanto que obedecía a la práctica habitual marcada por la constitución tradicional navarra de que únicamente el legislativo navarro podía intervenir, previa convocatoria del monarca del mismo, en cualquier cosa o "hecho granado" que supusiera alteración de aquélla. De hecho, como se recordará, la Representación presentada por la Diputación de Navarra ante la Junta de Notables de Bayona de 1808 terminaba pidiendo a José I, además de la conservación de la "constitución particular" navarra, "la congregación de las

93 Actas de las sesiones secretas de las Cortes Generales Extraordinarias de la Nación española que se instalaron el dia 24 de septiembre de 1810 y cerraron sus sesiones el 14 de igual mes de 1813, de las celebradas por la diputación permanente de Cortes y de las secretas de las Cortes Ordinarias, op. cit., p. 864.

94 Hasta ahora los únicos autores que se han hecho eco del contenido de estas informaciones de Villanueva en relación con la petición navarra de convocatoria de las Cortes navarras para la jura de la constitución han sido Mina Apat y el redactor de estas líneas. Cfr. María Cruz Mina Apat, Fueros y revolución liberal en Navarra, op. cit., p. 68 y Fernando Mikelarena Peña, "Acerca de la compatibilidad entre la Constitución de 1812 y los Fueros: el caso de Navarra", Sancho el Sabio, 2010, 33, p. 43. Otros autores han recogido sólo la cita de las actas oficiales.

95 Joaquín Lorenzo Villanueva, Mi viaje a las Cortes. Obra inédita, op. cit., p. 520. 
Cortes de Navarra" por ser "la convocación a Cortes privativa de sus Soberanos" y por estar aquélla "ceñida en los estrechos límites de su poder, que recivió de los Estados", y "que la imposibilitan, y a sus representantes de aspirar a otro medio".

Como se ve, Villanueva nos habla de un único memorial, presentado por Miguel Escudero y que vendría firmado presumiblemente por él mismo y por otros tres miembros de la Diputación del Reino de Navarra disuelta en 1809, en el que se solicitaba permiso para la reunión del Congreso navarro para publicar y jurar la Constitución a imitación de lo que habían hecho las Juntas Generales de Vascongadas a requerimiento de las Cortes Españolas.

Antes de seguir, es importante reseñar que uno de los firmantes de la Representación, Miguel Escudero, como se recordará representante oficial de la Diputación en Bayona y miembro de la Diputación errante fugada de Pamplona en agosto de 1808, habia sido nombrado Jefe Político de Navarra el 23 de julio de 1813, aunque en aquellos meses turbulentos con la presencia de la División de Espoz y Mina y de las tropas anglolusoespañolas su presencia en Navarra no comenzará a ser efectiva hasta el 14 de septiembre para organizar como presidente de la Junta Electoral de Navarra las elecciones de diputados a Cortes y de la nueva Diputación Provincial que tendrían lugar en Estella los día 25 y 26 de ese mes.

Por lo tanto, un mes después de su nombramiento, Miguel Escudero, miembro de la Diputación anterior y presidente futuro de la nueva Diputación provincial, solicitaba en vano, junto con otros antiguos miembros de la corporación ya extinguida y del único diputado navarro en Cádiz, que se convocaran las Cortes navarras para aprobar la Constitución, demostrando con ello su respeto por los mecanismos institucionales tradicionales del reino navarro. Esto es, desde la Diputación navarra vigente hasta 1809 se pensó a la altura de 1813, y sin que quedara clara el grado de autoridad y de legitimidad de aquel órgano extinto en la práctica desde hacía cuatro años, además de jurídicamente abolida desde marzo de 1812, en legitimizar el texto constitucional gaditano según los cánones constitucionales tradicionales navarros de la manera que fuese. Sin embargo, de la respuesta dada a la petición se colige que la no mención de las Cortes navarras entre los organismos que debían publicar y jurar la Constitución en el Decreto CXXXIX de 18 de marzo de 1812 era totalmente intencionada en cuanto que se consideraba que los Tres Estados navarros tenían un carácter superior, por su naturaleza legislativa, a las Juntas Generales de las Provincias Vascongadas ${ }^{96}$, siendo esa la razón de que éstas pudieran reunirse y aquéllos no puesto que la reunión del Congreso navarro iría en contra de uno de los principios fundamentales del régimen instaurado por las Cortes gaditanas, el de la instauración de un único cuerpo legislativo para la totalidad del Estado. En cierta forma, se repetía la situación de Bayona de 1808: aunque el artículo 144 del estatuto constitucional bayonés planteaba la revisión ulterior de los fueros vasconavarros, el resto del articulado era en absoluto compatible con ellos y, desde luego, hablaba en contra del mantenimiento de las Cortes navarras y del resto del entramado constitucional propio navarro.

96 Nótese que en la respuesta de las Cortes españolas no hay mención alguna a la diferencia en la composición de unas y otras, sino sólo a su nivel competencial. 
Además, las Cortes españolas y la Regencia, considerando lo sucedido en Vizcaya, podian temer que las Cortes navarras, en virtud de sus competencias (aunque también, aunque no se diga, de su composición y de su forma de funcionamiento, en las que el alto clero absolutista ya tenía de por sí un peso determinante), no se limitaran, tal y como recordaba Mina Apat"7, a "sancionar foralmente la nueva legalidad para evitar reclamaciones futuras", sino que se animaran a diseñar escenarios de compatibilidad entre la Constitución española y la Constitución navarra, tratando de mantener fórmulas de mantenimiento de poder local, o que incluso intentaran ir más allá.

No hay que olvidar que la conformación de la nueva diputación provincial y la elección de diputados a Cortes de final de septiembre de 1813 evidencian un notorio control por parte de los absolutistas y de los realistas moderados del escenario político navarro, incluso a través del nuevo sistema electoral indirecto, sin que pueda visualizarse una presencia minima de liberales en las instituciones locales o provinciales que apoyaran el constitucionalismo gaditano.

Según se deduce del análisis de las elecciones a diputados a Cortes $^{98}$, en las elecciones para Diputados a Cortes celebradas en Estella el 25 de septiembre de 1813, siete de los nueve votos fueron en la primera elección para el ultraabsolutista Veremundo Arias y Texeiro, obispo de Pamplona. En esa elección los electores valoraron la fidelidad a la alta dignidad episcopal pamplonesa, cuyo reaccionarismo a ultranza era ya público y notorio, así como su nula relación con las autoridades liberales, por encima de una persona como Dolarea que aunaba un absolutismo moderado con una valía demostrada en defensa de la constitución histórica de Navarra desde los tiempos de la Asamblea de Bayona y que había sabido tejer una cierta red de relaciones entre los parlamentarios gaditanos desde que se asentara en 1809 en tierras andaluzas. Las elecciones del segundo y del tercero diputado a Cortes sugieren que los elegidos, Areizaga y Dolarea, suscitaban mucha menor unanimidad, con una división casi a partes iguales entre los electores. La elección de los diputados a Cortes finalmente elegidos muestran una querencia de los electores hacia candidatos claramente reaccionarios (caso de Arias y Teixeiro) o dentro de las filas del realismo moderado (caso de Dolarea o Areizaga), querencia que, en el caso del primero, suponía una clarísima supeditación de las posibles reivindicaciones navarras, entre ellas las relativas a la constitución histórica, a la estrategia antidoceañista de los absolutistas. En el caso de la lección de la nueva diputación provincial, la elección de absolutistas radicales como Joaquín Javier Úriz, prior de Roncesvalles, que obtuvo por unanimidad los nueve votos totales en la votación de primer diputado, o como Joaquín Elio y Olondriz, que obtuvo ocho votos en la votación para segundo diputado, recabando los demás apoyos mucho más bajos, teñían la nueva corporación de los mismos componentes reaccionarios.

97 María Cruz Mina Apat, Fueros y revolución liberal en Navarra, op. cit., p. 68.

98 Analizadas a través de la documentación existente en AGN, Sección de Reino, Cortes, su celebración, poderes reales, convocatorias y poderes de los pueblos a sus procuradores, legajo 11 , Legajo 11, Carpeta 22: Actas formadas por las Juntas electorales de los partidos de Sangüesa, Olite, Tudela, Puentelareina y Estella sobre el nombramiento de electores de partido para elegir los diputados a Cortes (1813). 
Por otra parte, entre las causas de la escasa presencia de liberales, puede pensarse en la influencia de que, al ser ocupada desde febrero de 1808 hasta el 31 de octubre de 1813, fecha ésta en que fue levantado el cerco por la tropas de Wellington, Pamplona fue la última capital de provincia liberada, no habiendo posibilidad de que en ella se publicara ningún periódico liberal antes. Tampoco a partir de noviembre de 1813 se publicará ningún periódico de esa tendencia ideológica, a diferencia de lo que sucedió en las capitales de Vascongadas en las que surgieron varias iniciativas (El Bascongado, el Correo de Vitoria, el Periódico de San Sebastián y Pasajes, la Papeleta de Oyarzun), dato éste que ha servido para concluir sobre la debilidad del primer liberalismo en Navarra y su ubicación social entre la burguesía urbana ${ }^{99}$. Con todo, se ha afirmado que a pesar de la breve experiencia constitucional en Navarra, del verano de 1813 a la primavera de 1814, el igualitarismo constitucionalista prendió entre algunos sectores rurales que exigieron la abolición de prácticas feudales y que el clero y la nobleza contribuyeran también a las cargas fiscales dimanadas de la coyuntura bélica y exigidas por el ejército francés, las tropas anglolusas y españolas y la guerrilla a cuyo mando estaba Espoz y Mina. Se ha subrayado el júbilo con el que se acogió la proclamación de la Constitución y que, en cuanto a la asunción de su contenido, los campesinos navarros manifestaron "actitudes favorables al cambio" y "percibían el espíritu de la nueva legislación", reflejando la existencia de conflictos sociales de carácter antiseñorial y contra el clero ${ }^{100}$.

Sea como sea, ni en la antigua Diputación del Reino vigente hasta 1809 ni en la nueva Diputación provincial surgida en septiembre de 1813 se advertirá la presencia de una sensibilidad liberal. Ello hará que en Navarra, al contrario de lo que sucedió en la Baja Navarra en 1789 donde el Tercer Estado se mostró receptivo en los Estados Generales a los cambios impulsados desde París en relación con la supresión de los privilegios propios del Antiguo Régimen, no se perciban los posicionamientos de clase diferentes en relación con las posturas a $\operatorname{adoptar}^{101}$.

Además, también es preciso tener en cuenta la negativa imagen que ya desde febrero de 1813 tenía para la Regencia el obispo de Pamplona, cabeza de dicho estamento clerical en el legislativo navarro, como consecuencia de la Instrucción Pastoral que publicó entonces junto con otros prelados y en la que se identificaba a los doceañistas con los invasores franceses y les acusaba de conspirar y legislar contra la religión y la patria ${ }^{102}$. Aunque la pastoral no se reimprimió en Pamplona

99 Javier Fernandez Sebastián, "Opinión pública, prensa e ideas politicas en los origenes de la Navarra contemporánea, 1762-1823”, Príncipe de Viana, 188, 1989, p. 611-612; Maria Cruz Mina Apat, Fueros y revolución liberal en Navarra, op. cit., p. 71.

100 Joseba de la Torre, Lucha antifeudal y conflictos de clase en Navarra, 1808-1820, Bilbao, Universidad del País Vasco, 1992, p. 24-33.

101 Fernando Mikelarena Peña, "La Constitución Histórica navarra y el surgimiento del estado liberal. El espejo bajonavarro en 1789”, op. cit.

102 La Instrucción pastoral de los ilustrísimos obispos de Lérida, Tortosa, Barcelona, Urgel, Teruel y Pamplona al clero y pueblo de sus diócesis, fechada el 12 de diciembre de 1812, sería publicada por primera vez en Mallorca en febrero del año siguiente, conociendo varias ediciones y reimpresiones más en los dos años siguientes en Santiago, Valencia, Málaga y Manresa. En esa Instrucción Pastoral se comienza afirmando que la Religión ha constituído un baluarte contra los franceses, equiparados a los sarracenos conquistados de España en el siglo octavo (pp. 2-3), , añadiéndose más tarde que la resistencia y la victoria habian sido debidas "al amor de la Religión, al amor del Rey, y al amor de la Patria, que son inconquistables, porque llevan consigo la 
por indicación del propio obispo al provisor de la diócesis ${ }^{103}$, el documento se difundió muchísimo en Navarra ya que un capuchino introdujo 400 ejemplares ${ }^{104}$. El contenido de esa Instrucción Pastoral sería socializado y vulgarizado entre la población navarra a través de las homilias por los curas y predicadores, llegando a todos los rincones. En relación con esto último, no hay que olvidar la muy mayoritaria adscripción del clero secular y regular navarro a las tesis reaccionarias desde fechas tempranas. Como una muestra de lo que estamos diciendo, recordemos que en las listas de suscriptores de las Cartas del Filósofo Rancio, un auténtico best-seller de la reacción en aquella época, en tomos publicados a la altura de 1825 aparecen, según nuestro cómputo, nada menos que 293 navarros, 63 laicos y los restantes eclesiásticos, repartidos por toda la geografia navarra ${ }^{105}$.

Volviendo a la respuesta de las Cortes a la petición navarra, hay que recalcar que la negativa de aquéllas no significaba ya sólo silencio o mutismo: indicaba de forma explícitamente la supresión del sistema constitucional tradicional navarro en cuanto que conllevaba la imposibilidad de reunión de los Tres Estados navarros y, subsiguientemente, la de la Diputación que dimanaba de ella. Asimismo, independientemente de las dudas sobre la capacidad de adecuación al nuevo marco del legislativo navarro a causa de sus características internas de configuración y de reglamento (lo que será el factor clave argumentado desde 1837 por Yanguas y Miranda al diseñar la solución de 1841 de modificación de fueros ${ }^{106}$ ), la imposibilidad de reunión del Congreso navarro, y la eliminación de la Diputación como órgano subsidiario del anterior, obligaba al desmantelamiento de las instituciones navarras sin dar ninguna opción de supervivencia de las mismas fundamentada en su hipotética reestructuración con arreglo a los nuevos parámetros del liberalismo. Todo ello nos trae a la memoria lo sucedido en 1789 , no sólo con las reivindicaciones bajonavarras expresadas en el Tableau editado por Polverel, sino sobre todo con las de los labortanos que pensaban que su

protección del Cielo, con todos los intereses de la tierra, y la unión más íntima de todas las clases del Estado, reunidas y estrechadas con estos lazos indisolubles" (p. 4). De la execración de los franceses y de la apología del Altar, el Trono y la Patria se pasa posteriormente a la condena de los liberales identificados con los invasores (pp. 5-8), hasta el punto de afirmarse lo siguiente en contra de la constitución gaditana: las máximas de los franceses "vestidas a la Española, y disfrazadas sagazmente de reformas por escritores domésticos que blasonan tanto de amigos de la Patria, y de Católicos Apostólicos Romanos, pueden seducir más fácilmente a los incautos baxo el falso sobreeescrito de patriotas y de amigos nuestros; siendo realmente como aparecen en sus escritos, los enemigos más pérfidos de la Religión y de la Patria, y los seductores más artificiosos y más perjudiciales en España que los Franceses mismos" (p. 9).

103 Maria Concepción Laborie Erroz, "Navarra ante el constitucionalismo gaditano", Príncipe de Viana, 30, 1969, p. 54.

104 Antonio Elorza y Carmen López Alonso, Arcaísmo y modernidad: pensamiento politico en España, siglos XIX-XX, Madrid, Historia 16, 1989, p. 14.

105 Nuestra estimación se fundamenta en las listas de los tomos IV y V, ambos publicados en 1825, de la obra Cartas críticas que escribió el Rmo. Padre Maestro Fr. Francisco Alvarado del Orden de Predicadores o sea el Filósofo Rancio en las que con la mayor erudición y gracia se impugnan las doctrinas y máximas perniciosas de los nuevos reformadores, y se descubren sus perversos designios contra la Religión y el Estado.

106 Fernando Mikelarena Peña, "La cuestión foral en relación con Navarra en la opinión publicada anterior e inmediatamente posterior a la ley de 25 de octubre de 1839", Iura Vasconiae: Revista de Derecho Histórico y Autonómico de Vasconia, 9, 2012, pp. 173-175 y 181-185. 
Biltzar no era, por su misma composición, incompatible con los nuevos aires revolucionarios que, por otra parte, desde dicha asamblea apoyaban con entusiasmo ${ }^{107}$. Sea como sea, entendemos que esa cuestión es tremendamente importante en cuanto que se centra en una de las claves de lo que ocurrirá un cuarto de siglo después. A partir de 1837 los inspiradores del pacto de 1841, tanto por parte navarra como por parte del Estado, también se fundamentarán en la incompatibilidad entre las instituciones tradicionales navarras y el marco de la Constitución de 1837, no planteando en modo alguno por su parte ningún proceso de aggiornamento de las Cortes navarras, quizás porque consideraban imposible que tuviera lugar desde dentro, quizás porque de ningún modo podia dejarse subsistir un cuerpo legislativo navarro limitador del cuerpo legislador estatal ni tampoco el bilateralismo al que ello podía conducir ${ }^{108}$.

Los aspectos que estamos planteando no constituyeron arcanos que se olvidaron tan pronto como se sustanció su negativo desenlace sino que permanecieron indelebles en la memoria de las personas involucradas, siendo una lección a tener en cuenta de cara a situaciones que tuvieron lugar más adelante.

En la Representación entregada a Fernando VII el 20 de mayo de 1814 por Francisco Javier de Elío y Joaquín de Elío, el primero capitán general del $2^{\circ}$ ejército ${ }^{109}$ y el segundo miembro de la diputación y "legado especial" de la misma, y que había sido elaborada por la corporación provincial, dimitida unos dias antes, para la reposición de los fueros. se hacía hincapié en el déficit de legitimidad que la Constitución gaditana tenía en relación con Navarra al no permitirse que el legislativo navarro la debatiera, tal y como habian hecho las Juntas Generales vascongadas. En el documento se decía textualmente que la Constitución de Cádiz "que siempre detestó el Reino, y que aun de hecho ni llegó a implantarse por sus legitimos representantes, esto es, por los Tres Estados, congregados que debían ser al efecto en Cortes Generales y en quienes con su Soberano residen únicamente las facultades para variar, añadir o aclarar el precioso tesoro de sus instituciones fundamentales". En la representación también se recordaba que se había solicitado a las Cortes de Cádiz "la convocación de las de Navarra, con arreglo a su particular organización, por medio de su diputado suplente, luego que la mayor parte del Reino se vió libre de la opresión enemiga, como constará en las actas de aquellas Cortes"110.

107 Fernando Mikelarena Peña, "La Constitución Histórica navarra y el surgimiento del estado liberal. El espejo bajonavarro en 1789”, op. cit.

108 Fernando Mikelarena Peña, "La cuestión foral en relación con Navarra en la opinión publicada anterior e inmediatamente posterior a la ley de 25 de octubre de 1839”, op. cit.

109 Hay que recordar que Francisco Javier de Elío, capital general de Valencia uno de los ejecutores del plan de acción que, tras la presentación del Manifiesto de los Persas, brindaría apoyo militar a Fernando VII.

110 Hermilio de Olóriz, Navarra en la guerra de la independencia; biografía del guerrillero D. Francisco Espoz (Espoz y Mina), y noticia de la abolición y restablecimiento del régimen foral, op. cit., pp. 296-297. La representación original (que se encontraba en AGN, Legislación general y contrafueros, legajo 22, documento 33 y cuyo título era Representaciones entregadas al Rey por el Teniente general Don Javier de Elio y don Joaquin su hermano a nombre del Reino de Navarra para el restablecimiento de sus fueros según estaban antes de haberse publicado la Constitución) falta desde 1973, según consta en el inventario correspondiente. Mina Apat (María Cruz Mina Apat, Fueros y revolución liberal en Navarra, op. cit., p. 73) subraya el sabor integrista del texto y su 
Con el fin de evitar la recriminación que figuraba en esa representación de la Diputación de mayo de 1814 en la que se subrayaba el déficit de legitimidad de aquella Carta Magna de la monarquía española en Navarra por no haber sido aprobada por el legislativo navarro, a mediados de marzo de 1820, con la entrada en vigor de nuevo del régimen constitucional, el síndico del reino Florencio García Goyena, persona de ideología liberal que en 1820-1823 y tras 1834 ocuparía cargos importantes dentro de la carrera política y judicial llegando a la presidencia del Tribunal Supremo en 1843 y a ser Ministro de Gracia y Justicia y Presidente del Gobierno en 1847111, plantearía la convocatoria inmediata de las Cortes navarras por parte del Gobierno con el "efecto solo de tratar de su incorporación lisa y llana con absoluta igualdad y unidad bajo el nuevo Régimen constitucional al resto de la Monarquía". El proponente pensaba, de forma demasiado simplista quizás, que los navarros responderian a ese ofrecimiento con una adhesión "voluntaria, sincera y durable", desapareciendo cualquier atisbo de resistencia ya que, a su juicio, con aquel trámite los navarros se unirian "gustosos a la gran familia española" al eliminarse los criterios de déficit de legitimidad ${ }^{112}$.

Un cuarto de siglo despues, en octubre de 1839, en el contexto del debate registrado en el Senado en relación con la ley que se aprobaría el 25 de ese mes relativa a la foralidad vasconavarra, el conde de Ezpeleta recordaría diferentes iniciativas promovidas por la Diputación para la salvaguarda del autogobierno navarro en 1813 y 1820. De esta forma, dijo: "En el año de 1814 [sic, por 1813], el diputado D. Miguel Escudero, persona bien conocida en Madrid, hizo aquí la protesta en nombre de la Diputación, protesta que le valió bastantes disgustos; y tanto que en los años del 20 al 21, habiendo sido nombrado jefe político de Navarra, hubo disgustos y no se le dejó tomar posesión a pretexto de que había protestado a favor de las Constituciones de Navarra. Como Diputado no pudo hacer otra cosa que protestar. En el año de 20 [1820, con la promulgación de nuevo de la Constitución de 1812 con el inicio del Trienio Liberal], D. Florencio Garcia Goyena estaba de diputado en Madrid, y la hizo, por cierto confidencial, al Sr. Sancho, con el objeto de que se reuniesen las Cortes de Navarra con el único objeto de tratar de la incorporación, para que fuese más legal y para que en ningún tiempo se pudiese reclamar; pero sucedieron los acontecimientos que son

condena de las novedades constitucionales. Asimismo, al referirse al referirse al argumento de falta de legitimidad de la Constitución gaditana por no haber sido promulgada por las Cortes navarras, señala la aparición por primera vez de "un argumento que algunos foralistas de todos los tiempos emplearán hasta nuestros días, no sólo para invalidar la Constitución de 1812, sino también más tarde la ley de 1841". La mencionada autora obvió que esa reivindicación estaba presente en la representación presentada por la Diputación en Bayona en 1808 y en las peticiones de los altonavarros en 1789, correspondiéndose con el procedimiento que prescribía la constitución navarra ante cualquier hecho significativo que supusiese su alteración, tal y como reconocería García Goyena en 1820.

111 Puede verse su biografia en Enciclopedia de Historia de España, vol IV. Diccionario biográfico, Madrid, Alianza Editorial, 1991, pp. 344-345. Disponible en Internet en la dirección http://www.xtec.es/ jrovira6/bio/gargoyen.htm.

112 AGN, Reino, Diputación del Reino, sus Síndicos y Secretario, Gefes políticos y Diputaciones Provinciales, Legajo 3, Carpeta 33. Cartas del Síndico don Florencio Garcia comisionado en Madrid comunicando a la Diputación sus ideas sobre la conducta que convendría seguir en Navarra con motivo de haberse restablecido la Constitución española (1820). 
Las apelaciones ante las Asambleas parlamentarias españolas al respeto a la ...

bien sabidos, y como yo me hallaba de guarnición en Pamplona cuando se pronunció, sé que no hubo lugar a nada y la cosa quedó en tal estado"113.

\subsection{Una posible razón añadida de la solicitud de 20 de agosto de 1813 de convocatoria de Cortes navarras.}

En el apartado anterior hemos hablado de la solicitud de permiso para la reunión de las Cortes navarras presentada el 20 de agosto de 1813, según las versiones, bien simultáneamente por el diputado suplente y por diversos miembros de la Diputación vigente hasta 1808, bien por éstos últimos, y la hemos razonado en virtud de que ello concordaba con las pautas habituales prescritas por la constitución histórica navarra ya que cualquier modificación de ésta debía ser autorizada por el legislativo navarro, tal y como recordó la Diputación en repetidas ocasiones, antes y después de entonces, y tal y como traerá a colación uno de los últimos sindicos de la Diputación, Ángel Sagaseta de Ilurdoz, en 1839-1840 en relación con el poder que debía negociar desde Navarra con el Estado la ley de abolición/modificación de fueros de octubre de 1839 en un folleto que fue secuestrado por el Jefe Político y que suponía una defensa a ultranza del constitucionalismo propio ${ }^{114}$.

Sin embargo, además de todo ello, hay una cuestión que todavía no queda clara. El hecho de que para finales de agosto de 1813 gran parte de Navarra se hubiera librado ya de los invasores franceses, contando ya, como veremos, con un jefe político designado por la Regencia, precisamente uno de los miembros más relevantes de la extinta Diputación del Reino y que había sido uno de los dos delegados enviados a Bayona en 1808, ¿es la única circunstancia que debe considerarse? ¿O cabe alguna más?.

Inicialmente no habiamos considerado ninguna otra eventualidad y así lo reflejamos en un artículo que publicamos hace unos años y en el que anticipamos un avance de la cuestión ${ }^{115}$. Sólo en los últimos meses nos hemos percatado de un extremo que pudo tener su importancia, añadiéndose a todo lo expresado más arriba. Y es que el día trece de julio se presentó en las Cortes el primer proyecto de ley sobre la responsabilidad de los infractores de la Constitución sometido a pleno el 13 de julio de 1813, debatiéndose casualmente

113 "Los fueros de las Provincias Vascongadas y Navarra en las Cortes de 1839", Documentación Administrativa, 1977, 175, pp. 376-377. Dicho artículo recoge la transcripción de todos los textos de los diarios de las sesiones del Congreso de los Diputados y del Senado relativos al debate de la ley de 1839, con la sola excepción de los relativos a cuestiones incidentales que no tocan la sustancia del mismo.

114 E1 folleto de Ángel Sagaseta de Ilurdoz, titulada Fueros fundamentales del reino de Navarra y Defensa legal de los mismos, conoció dos ediciones, una publicada en Valencia el 21 de diciembre de 1839 y otra, de reedición de la anterior, publicada en Pamplona en 1840, ambas secuestradas. Ángel Sagaseta de Ilurdoz fue Sindico Consultor de las Cortes de Navarra desde 1817 hasta 1833, fecha en que fue desterrado a Valencia por sus simpatias con el carlismo y por sus estrechos vínculos con militares carlistas como Zumalacárregui o Zaratiegui. Más datos sobre su persona y sobre la obra en cuestión en Fernando Mikelarena Peña, "La cuestión foral en relación con Navarra en la opinión publicada anterior e inmediatamente posterior a la ley de 25 de octubre de 1839", op. cit.

115 Fernando Mikelarena Peña, "Acerca de la compatibilidad entre la Constitución de 1812 y los Fueros: el caso de Navarra”, op. cit. 
el mismo los días 18, 19, 20 y 22 de agosto, aunque sin zanjarse la cuestión, lo que se plantearía en más ocasiones, continuando irresuelta cuando Fernando VII abolió la constitución en mayo del año siguiente ${ }^{116}$.

Pues bien, el primer artículo de dicho proyecto de ley era taxativo respecto a la total inviabilidad de cualquier intento de conciliar la constitución española de 1812 con cualquier peculiaridad politicoinstitucional surgida de alguna pretendida constitución alternativa existente sobre el solar hispano. Ese artículo decía: "Cualquiera español, de cualquier clase y condición que sea, que de palabra o por escrito tratase de persuadir que no debe guardarse en las Españas, o en alguna de sus provincias la Constitución política de la Monarquía en todo o en parte, será declarado indigno del nombre español, perderá todos sus empleos, sueldos y honores, y será expulsado para siempre del territorio de la Nación, ocupándosele además sus temporalidades si fuere eclesiástico. También se expulsará del Reino para siempre al extranjero que hallándose en territorio español cometa el propio delito"117. Dejando de lado el artículo 2, que aludía a una defensa a ultranza del confesionalismo católico del Estado constitucionalista gaditano ${ }^{118}$, los artículos 3 y 4 reincidian en un tono abrumadoramente uniformizador, especialmente el primero de ellos que afirmaba: "El que alterase, o conspirase directamente y de hecho, a destruir o alterar el gobierno monárquico moderado hereditario que la Constitución establece, o a que se confundan en una persona o cuerpo las potestades legislativa, ejecutiva y judicial, o a que se radiquen en otras corporaciones o individuos, será también perseguido como traidor, y condenado a muerte"119. Ni que decir tiene que este artículo ahogaba cualquier esperanza de subsistencia de otro órgano legislativo en el seno del Estado, tal y como se afirmaría en la respuesta dada el día 20 de agosto a la petición mencionada.

Los demás artículos son menos importantes para nuestros fines. En los artículos 5, 6, 7, 8 y 9 se hablaba de los castigos en que podían incurrir jefes políticos, alcaldes o cualquier persona en relación con la no celebración de juntas electorales de parroquia con arreglo a la constitución. En los artículos 11, 12, 13 y 14 se legislaba contra los que intentasen impedir reuniones de las Cortes o de la Diputación permanente de las mismas, impidiéndose la eventualidad de que el rey lo pudiera ordenar. La mayoría de los artículos restantes, hasta el último, el 33, hablan de la protección a los ciudadanos en caso de detención y de que los

116 Un segundo proyecto se presentó el 30 de octubre de 1813, retomándose por el pleno en marzo y abril de 1814. Aunque la mayoría del articulado estaba aprobado, el decreto abolitorio fernandino impidió la aprobación de la ley por el pleno. Finalmente, gran parte de los artículos pasarían al Código Penal de 1822 (arts. 188 y ss sobre los delitos contra la libertad de la nación).

117 Diario de sesiones de las Cortes Generales y Extraordinarias 1811. No 97 (01-01-1811) al No 454 (31-12-1811), Cádiz, s. n., 1811, Sesión de 13 de julio de 1811, Página 5698.

118 "El que conspirase directamente y de hecho a establecer otra religión en las Españas, o a que la Nación española deje de profesar la religión católica, apostólica, romana, será perseguido como traidor, y sufrirá la pena de muerte". Ibidem.

119 Ibid., pp. 5698-5699. El artículo 4 decía: "El que alterase, o conspirase directamente y de hecho, a destruir o alterar el gobierno monárquico moderado hereditario que la Constitución establece, o a que se confundan en una persona o cuerpo las potestades legislativa, ejecutiva y judicial, o a que se radiquen en otras corporaciones o individuos, será también perseguido como traidor, y condenado a muerte". 
delitos de infracción de la Constitución serian juzgados por la jurisdicción ordinaria $^{120}$.

Por lo que respecta al debate, celebrado, como ya se ha dicho, los dias 18,19 , 20 y 22 de agosto, no hay mucho de que hablar. Quizás la discusión más relevante fue en torno al artículo primero. El diputado Mejía señaló que la redacción debía ser más clara porque no se podian confundir quien atacara la Constitución, "persuadiendo su inobservancia" con quien la censurara o criticara, "manifestando sus defectos", ya que aquello debia "ser tenido por el mayor crimen a los ojos de cualquier patriota, porque atacar la Constitución lo mismo es que tirar a destruir la Patria, la cual sin Constitución no puede existir", mientras que lo segundo podía "acreditarse de imprudente, sin que por esto sea un criminal el que lo ejecute". Calatrava agradeció su observación, pero replicó que tal matiz estaba recogido en el texto tal y como había sido redactado. Dijo que la ley no se refería a quienes habían manifestado sus opiniones sobre la Constitución, "pero sin apartarse de que se observe y cumplirla puntualmente", sino a aquéllos "que de mala fé conspiran contra la observancia de la Constitución: de aquellos, en una palabra, que traten de persuadir que no se debe guardar en todo o en parte. Estos son delincuentes, y merecen un castigo"121. Aparte del artículo segundo que dió lugar a una discusión larga por el empeño del sector ultramontano de proteger la ortodoxia católica hasta la exasperación, mucho más allá de lo que era acorde con el precepto constitucional correspondiente, los demás artículos importantes que mencionamos más arriba se aprobaron sin discusión.

Sin duda alguna, independientemente de la razón vinculada con el procedimiento dictado por la constitución histórica navarra para su modificación, que obligaba a la reunión de las Cortes navarras, en la solicitud del 20 de agosto hay, considerando el texto de este proyecto de ley, un aroma de último recurso puesto que, mientras que el texto constitucional optaba por el silencio en relación con las instituciones navarras, dicho proyecto las ilegalizaba de facto al entender que no existía ninguna otra legalidad fuera de la que orbitaba sobre aquél. La solicitud se consideró en el peor momento, cuando el pleno había asumido que una pretensión así era una infracción flagrante de la Constitución. Desgraciadamente, no hemos podido recoger ningún testimonio documental de la frustración de los representantes navarros ante esa postura.

\section{A MODO DE CONCLUSIÓN.}

Tras el fracaso bajonavarro de 1789 ante la Asamblea nacional francesa, Bayona en 1808 y Cádiz en 1810-1813 serían las dos siguientes ocasiones en las que la constitución histórica de Navarra confrontó con el nuevo constitucionalismo liberal. En el caso bayonés, la aparente tabla de salvación de hipotética adecuación ulterior que brindaba el artículo 144 no nos debe hacer olvidar que el resto del articulado del estatuto constitucional aprobado alli era absolutamente incompatible con el entramado constitucional navarro. En el caso gaditano, la abolición de dicho entramado se hizo de forma menos diplomática y tuvo lugar por partida doble, la primera en el propio texto constitucional, la

\footnotetext{
${ }^{120}$ Ibid., pp. 5699-5700.
}

121 Ibid., p. 5984. 
segunda por no permitirse la reunión de las Cortes navarras para jurar aquél. Tanto desde el ángulo procedimental como desde el de los actores implicados o el de los discursos argumentados, el proceso fue relativamente complejo, bastante más de lo que pudiera pensarse desde una primera aproximación.

Comencemos con el hecho de la representación navarra. En Bayona las quejas de la Diputación relativas al hecho que suponía la circunstancia de representar en un foro extraño y al de que fuera aquélla la que designara a los delegados, obviándose a las Cortes navarras competentes para ello, fueron ignoradas por las autoridades napoleónicas y debieron ser soslayadas por la misma corporación navarra. A su vez, no caben dudas de la competencia de la delegación navarra, que estuvo en todo momento en contacto con el cuerpo al que obedecía, supo coordinar esfuerzos con él, concertó el trabajo argumentativo con los representantes de las diputaciones vascongadas y realizó un trabajo diplomático de alcance ante los altos funcionarios josefinos de cara a conseguir una ambigua solución diferida, que era lo máximo que se podia lograr.

En Cádiz ni siquiera se planteará el problema de la representación en un foro parlamentario ajeno al regulado por el propio ordenamiento constitucional navarro, no siendo planteado en ningún momento la no participación en él, como si ya ese tema fuera una batalla perdida. Es más, miembros de la Diputación en el exilio tratarán de incrementar la representación navarra en las Cortes unicamerales gaditanas por medio de la inclusión de delegados por el apartado de las Juntas Superiores y por el de las ciudades, sin que conste ninguna objeción como las argüidas en Bayona ni de ningún otro tipo.

Finalmente, aquellas mismas personas estarán, o debieron estar, detrás de la designación del único comisionado de Navarra ante las Cortes en aquel proceso constituyente, el delegado suplente Francisco de Paula Escudero. Su prácticamente nula actividad en aquel foro choca enormemente con la circunstancia de que fuera hermano de uno de los representantes de la Diputación navarra en Bayona en 1808 y uno de los miembros más activos y comprometidos con el marco políticoinstitucional navarro de la Diputación fugada de Pamplona a finales de agosto de 1808 y luego subsistente durante algunos meses, aunque sin operatividad por su carácter itinerante por zonas de Aragón, Castilla y Rioja. La elección de aquél es absolutamente ininteligible, toda vez que uno de los siete compromisarios que lo eligió, el síndico de la Diputación Alejandro Dolarea, era el máximo experto en aquellos momentos en temas constitucionales navarros, tal y como acredita su labor publicística en aquellos años, y, además, desde dos años antes de septiembre de 1810, se movía con soltura en los ambientes preconstituyentes andaluces.

Pasando de las personas a los procedimientos y a los contenidos argumentativos, en Bayona y en Cádiz se aprecian disimilitudes notorias. En la ciudad labortana la Diputación navarra presentó una representación al Emperador, acompañándola tanto de un texto de descripción de la constitución histórica navarra, obra sin duda del síndico Alejandro Dolarea, que la interpretaba paraliberalmente, como de una actividad diplomática, en unión de los delegados de las representantes vascongadas, ante Azanza y Urquijo.

Posteriormente, entre el otoño de 1808 y marzo de 1812, la presencia de Dolarea en diferentes comisiones oficiales, y los documentos que elaboró sobre el tejido constitucional navarro en los debates previos a la apertura de las Cortes 
gaditanas manteniendo el mismo hilo argumentativo de Bayona (y que no deben de ser contemplados como elaborados exclusivamente para dotar de legitimidad historicista a los nuevos planteamientos constitucionales, sino que deban de ser percibidos también como dotados de una finalidad de defensa de aquél en la medida en que Navarra conservaba todavia, al igual que las Vascongadas, su sistema constitucional foral tradicional), no tuvieron proyección en la labor parlamentaria del único diputado por Navarra en el foro gaditano.

Por otra parte, aunque cabe pensar que la autodisolución en la práctica de la Diputación en 1809 imposibilitaba cualquier labor de mediación por su parte ante cualquier otra institución y organismo y que la rigidez de los procedimientos establecidos por los doceañistas era un obstáculo añadido de cara a la consideración de las opiniones de los cuerpos jurídicos tradicionales existentes hasta entonces, no deja de llamar la atención la circunstancia de que en el lapso de tiempo que va de 1809 a 1812 sea inexistente cualquier tipo de reclamación institucional por parte de la Diputación navarra que recuerde a la formulada por la Baja Navarra en 1789 a los Estados Generales franceses o a la Asamblea Nacional francesa o a la remitida por aquélla a las autoridades napoleónicas en el contexto de la asamblea bayonesa de 1808.

La prohibición de reunión de las Cortes navarras por parte de las Cortes españolas hizo que el silencio de la Constitución de Cádiz en relación con el sistema constitucional foral navarro trocara, tras el rechazo a la representación de agosto de 1813, en una abolición expresa del mismo, no abriéndose siquiera la posibilidad a una convocatoria de aquéllas, tal y como prescribían los parámetros constitucionales navarros para cualquier modificación de la Constitución propia, siquiera circunscrita a la aceptación del nuevo ordenamiento constitucional estatal y a la renuncia voluntaria al autóctono.

Si ya de partida el nivel competencial, la composición y la forma de funcionamiento del legislativo navarro dificultaban el diseño de alguna solución creativa respetuosa de alguna forma con las instituciones forales navarras (lo que, desde luego, no se planteó ni por parte del gobierno, pero tampoco, por parte navarra desde donde a lo máximo que se llegó fue a los conservadores planteamientos de Dolarea), la intromisión en el asunto de la estrategia de los sectores absolutistas a través del obispo de Pamplona, autor seis meses antes de una Instrucción Pastoral incendiaria en relación con los doceañistas gaditanos y persona que ejercería la jefatura en el brazo eclesiástico en las Cortes navarras en caso de ser convocadas, imposibilitaba aquélla de facto.

Posteriormente, el curso de los acontecimientos entre el verano de 1813 y mayo de $1814^{122}$ hizo que la desconfianza de la Regencia y de las Cortes hacia la Diputación navarra no hiciera más que incrementarse, a causa de la capacidad de los realistas para aprovechar en su beneficio las posibilidades que brindaba el sistema electoral indirecto, de la escasa visibilidad de los liberales navarros en aquella coyuntura, y de la circunstancia de que a partir de septiembre meses las autoridades provinciales navarras contestarán repetidamente las órdenes de la Regencia.

122 Fernando Mikelarena Peña, "Acerca de la compatibilidad entre la Constitución de 1812 y los Fueros: el caso de Navarra", op. cit. 
De cualquier forma, queremos llamar la atención sobre las repercusiones que para liberales y absolutistas, y de cara a su arraigo entre la población navarra, tuvo la utilización que los segundos hicieron de la cuestión fueros/constitución en ese primer intento de instauración del Estado liberal y que, de hecho, fue letal para la constitución histórica de Navarra ante un hipotético primer intento de transacción que se escondiera después de la petición de convocatoria de las Cortes navarras hecho en Cádiz en agosto de 1813. Con todo, tampoco habría que olvidar que, en el curso de los años posteriores, el tema se enmarañaria notablemente con los ataques al sistema foral navarro por parte de los gobiernos absolutistas de Fernando VII ${ }^{123}$, de forma que la defensa del autogobierno navarro quedaría atrapado ya a partir de 1815 en una doble trampa, la relacionada con la polarización de la sociedad, en Navarra y en el conjunto del Estado, en dos bandos, el absolutista y el liberal, y la vinculada con el hecho empírico de que, en el fondo, ni absolutistas ni liberales miraban con simpatía a aquél.

Enviado el (Submission Date): 12/03/2015

Aceptado el (Acceptance date): 13/04/2015

123 Cfr. Rodrigo Rodriguez Garraza, Navarra de reino a provincia (1828-1841), op. cit., pp. 33141; Maria Cruz Mina Apat, Fueros y revolución liberal en Navarra, op. cit., pp. 60-173. 